\title{
An Initial Comparative Analysis of the CMMI Version 1.2 Development Constellation and the ISO 9000 Family
}

\author{
David H, Kitson, KAMO Consultancy \\ Robert Vickroy, ABS Quality Evaluations, Inc. \\ John Walz, The Sutton Group \\ Dave Wynn, Computer Sciences Corporation
}

March 2009

SPECIAL REPORT

CMU/SEI-2009-SR-005

Software Engineering Process Management

Unlimited distribution subject to the copyright.

\section{CarnegieMellon}


This report was prepared for the

SEI Administrative Agent

$\mathrm{ESC} / \mathrm{XPK}$

5 Eglin Street

Hanscom AFB, MA 01731-2100

The ideas and findings in this report should not be construed as an official DoD position. It is published in the interest of scientific and technical information exchange.

This work is sponsored by the U.S. Department of Defense. The Software Engineering Institute is a federally funded research and development center sponsored by the U.S. Department of Defense.

Copyright 2009 Carnegie Mellon University.

NO WARRANTY

THIS CARNEGIE MELLON UNIVERSITY AND SOFTWARE ENGINEERING INSTITUTE MATERIAL IS FURNISHED ON AN "AS-IS" BASIS. CARNEGIE MELLON UNIVERSITY MAKES NO WARRANTIES OF ANY KIND, EITHER EXPRESSED OR IMPLIED, AS TO ANY MATTER INCLUDING, BUT NOT LIMITED TO, WARRANTY OF FITNESS FOR PURPOSE OR MERCHANTABILITY, EXCLUSIVITY, OR RESULTS OBTAINED FROM USE OF THE MATERIAL. CARNEGIE MELLON UNIVERSITY DOES NOT MAKE ANY WARRANTY OF ANY KIND WITH RESPECT TO FREEDOM FROM PATENT, TRADEMARK, OR COPYRIGHT INFRINGEMENT.

Use of any trademarks in this report is not intended in any way to infringe on the rights of the trademark holder.

Internal use. Permission to reproduce this document and to prepare derivative works from this document for internal use is granted, provided the copyright and "No Warranty" statements are included with all reproductions and derivative works.

External use. This document may be reproduced in its entirety, without modification, and freely distributed in written or electronic form without requesting formal permission. Permission is required for any other external and/or commercial use. Requests for permission should be directed to the Software Engineering Institute at permission@sei.cmu.edu.

This work was created in the performance of Federal Government Contract Number FA8721-05-C0003 with Carnegie Mellon University for the operation of the Software Engineering Institute, a federally funded research and development center. The Government of the United States has a royalty-free government-purpose license to use, duplicate, or disclose the work, in whole or in part and in any manner, and to have or permit others to do so, for government purposes pursuant to the copyright license under the clause at 252.227-7013.

For information about purchasing paper copies of SEI reports, please visit the publications portion of our Web site (http://www.sei.cmu.edu/publications/pubweb.html). 


\section{Table of Contents}

Acknowledgements $\quad$ vi

Executive Summary viii

Abstract $\quad x$

1 Introduction and Overview 1

1.1 Background 1

1.2 Structure of this Report 1

1.3 Guidance for Specific Audiences 2

2 Overview of the CMMI Development Constellation 3

2.1 Scope of Application and Purpose 3

2.2 Background 3

2.3 Foundational Concepts and Terminology 4

2.3.1 Constellation 4

2.3.2 Process Areas 4

2.3.3 Maturity Levels 4

2.3.4 Capability Levels 4

2.3.5 Appraisal 4

2.3.6 Appraisal Team 5

2.3.7 Appraisal Requirements for CMMI (ARC) 5

2.3.8 Standard CMMI Appraisal Method for Process Improvement (SCAMPI) 5

2.3.9 SCAMPI (A, B, C) Family 5

2.3.10 SCAMPI Lead Appraiser 5

2.3.11 Institutionalization 5

2.3.12 Representation 6

2.4 Key Product Elements 6

2.5 CMMI Models 6

2.6 Appraisal 6

$\begin{array}{lll}2.7 & \text { Training } & 7\end{array}$

2.8 Supporting infrastructure 8

$\begin{array}{ll}\text { 2.8.1 Sponsorship } & 10\end{array}$

$\begin{array}{ll}2.8 .2 \text { Stewardship } & 10\end{array}$

$\begin{array}{lll}2.8 .3 & \text { CMMI Initiative } & 10\end{array}$

$\begin{array}{lll}2.8 .4 & \text { Product Transition and Development } & 10\end{array}$

$\begin{array}{ll}\text { 2.8.5 SEl Credentials Program } & 10\end{array}$

$\begin{array}{lll}2.9 & \text { Adoption } & 11\end{array}$

3 Overview of the ISO 9000 Family 13

3.1 Scope of Application and Purpose 13

$\begin{array}{lll}3.2 & \text { Background } & 13\end{array}$

$\begin{array}{lll}3.3 & \text { Foundational Concepts and Terminology } & 14\end{array}$

$\begin{array}{lll}\text { 3.3.1 Quality Management System } & 14\end{array}$

$\begin{array}{ll}\text { 3.3.2 Accreditation } & 15\end{array}$

$\begin{array}{lll}\text { 3.3.3 } & \text { Accreditation Body } & 15\end{array}$

$\begin{array}{lll}\text { 3.3.4 Certification } & 15\end{array}$ 
$\begin{array}{lll}\text { 3.3.5 Certification Body } & 15\end{array}$

$\begin{array}{lll}\text { 3.3.6 Registration } & 15\end{array}$

$\begin{array}{lll}3.3 .7 & \text { Registrar } & 15\end{array}$

$\begin{array}{lll}3.3 .8 & \text { Auditor } & 15\end{array}$

3.3.9 Audit 16

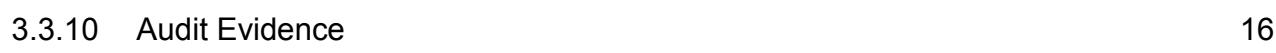

3.3.11 Audit Criteria 16

3.3.12 Competence 16

3.3.13 Certified Competence 16

3.4 Key Product Elements 16

$\begin{array}{lll}3.4 .1 & \text { Process Scope } & 16\end{array}$

$\begin{array}{ll}3.4 .2 & \text { Sector-Specific Variants }\end{array}$

$\begin{array}{lll}3.5 & \text { Appraisal } & 18\end{array}$

$\begin{array}{lll}3.6 & \text { Training } & 21\end{array}$

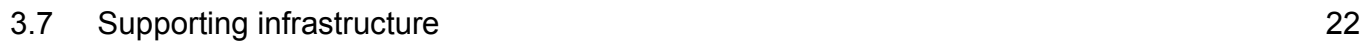

$\begin{array}{ll}3.8 \text { Adoption } & 22\end{array}$

4 Comparative Analysis $\quad 23$

$\begin{array}{lll}4.1 & \text { Terminology } & 23\end{array}$

$\begin{array}{lll}4.2 & \text { Key Product Elements } & 24\end{array}$

$\begin{array}{lll}4.3 & \text { Process scope } & 24\end{array}$

4.3.1 Organizational Scope $\quad 24$

4.3.2 Level 1 Coverage Comparison $\quad 25$

4.3.3 Mid-Level Coverage Comparison (CMMI-DEV, V1.2 to ISO 9001) 27

4.3.4 Mid-Level Coverage Comparison (ISO 9001 to CMMI-DEV, V1.2) 29

4.3.5 Treatment of Customer Satisfaction 33

4.3.6 Treatment of High Maturity 33

$\begin{array}{lll}4.4 & \text { Appraisal } & 34\end{array}$

4.5 Training of Lead Appraisers and Lead Auditors $\quad 35$

$\begin{array}{lll}4.6 & \text { Supporting infrastructure } & 36\end{array}$

$\begin{array}{lll}4.7 & \text { Adoption } & 36\end{array}$

$\begin{array}{lll}4.8 & \text { Comparative Summary } & 38\end{array}$

$\begin{array}{llr}\text { Appendix A: } & \text { Individual and Organizational Contributors } & 39\end{array}$

\begin{tabular}{lr} 
Appendix B: & List of Acronyms \\
\hline
\end{tabular}

$\begin{array}{ll}\text { Appendix C: Terminology Differences } & 43\end{array}$

$\begin{array}{ll}\text { Appendix D: } & \text { Body of Knowledge Resources }\end{array}$

$\begin{array}{lr}\text { References } & 49\end{array}$ 


\section{List of Figures}

Figure 1: Supporting Infrastructure for CMMI

Figure 2: Supporting Infrastructure for ISO 9001 
iv | CMU/SEI-2009-SR-005 


\section{List of Tables}

Table 1: Individuals who Have Completed CMMI-Related Training Courses 11

Table 2: Individuals who Have Received SEI CMMI Authorization Credentials 11

Table 3: Summary Comparison of the Content Relationships Between the Major Clauses of ISO 9001 and the CMMI-DEV, V1.2 Process Categories

Table 4: Detailed Comparison of how Major Clauses of ISO 9001 Overlap with the CMMI-DEV, V1.2 Generic Practices

Table 5: Mid-Level Comparison of the Content Relationships Between CMMI-DEV, V1.2 and ISO 9001

Table 6: Mid-Level Comparison of the Content Relationships Between ISO 9001 and CMMI-DEV, V1.2 Maturity Level 2 Process Areas

Table 7: Mid-Level Comparison of the Content Relationships Between ISO 9001 and CMMI-DEV, V1.2 Maturity Level 3 Process Areas

Table 8: $\quad$ Mid-Level Comparison of Content Relationships Between ISO 9001 and CMMI-DEV, V1.2 Maturity Level 4 and 5 Process Areas

Table 9: Comparison of Attributes of ISO 9001 and CMMI-DEV, V1.2

Table 10: A Comparison of Terminology Definitions for ISO 9000 and CMMI-DEV, V1.2 


\section{Acknowledgements}

Several groups contributed to the Rope Bridge project that produced this report; the groups and their membership are listed in Appendix A. Special mention is due to Lockheed Martin Integrated Systems and Solutions for its willingness to lead the effort by contributing the critical initial funding to get this initial report produced. Also worthy of special mention is the Z1 Quality Management committee of the American Society for Quality, which provided some of the energy needed to successfully complete this project. This support, coupled with the support of the Software Engineering Institute (SEI), contributed significantly to the completion of this work. Much of the membership of the Z1 committee is shared with the U.S. Technical Advisory Group (TAG) to TC176; this U.S. TAG represents the U.S. at the international level in matters relating to the International Standard Organization (ISO) 9000 family of standards. The SEI is the Capability Maturity Model ${ }^{\circledR}$ Integration $\left(\mathrm{CMMI}^{\circledR}\right)$ steward. As a result, the combined sponsorship for this work is, in a very real sense, a reflection of the combined views of the ISO 9000 and CMMI communities. 


\section{Executive Summary}

An increasing number of product-development organizations are "paying attention" to both ISO 9001 and the Development constellation of the CMMI Product Suite. This technical note compares and contrasts these two bodies of knowledge to help build a bridge between the ISO 9001 and CMMI communities that will promote mutual understanding.

While the two bodies of knowledge were developed independently and for different purposes, they have important connections and are largely consistent with each other.

Organizations that are implementing both ISO 9001 and the CMMI Development constellation will benefit from an understanding of areas that are covered fully by both bodies of knowledge, as well as areas not covered by both. This understanding can lead to efficiencies of operation, as well as better clarity for those responsible for implementation and operations. 


\section{Abstract}

This report is intended for organizations and individuals who have knowledge of either the Capability Maturity Model ${ }^{\circledR}$ Integration $\left(\mathrm{CMMI}^{\circledR}\right)$ Product Suite or the International Organization for Standardization (ISO) 9000 family of standards, and are interested in learning more about the other process standard. The CMMI for Development, Version 1.2 (CMMI-DEV, V1.2) model and the ISO 9001:2000 standard are compared, and their similarities and differences are noted. This report is not intended to be an exhaustive or authoritative comparison between the CMMI-DEV, V1.2 model and the ISO 9001:2000 standard, nor does it provide specific guidance for organizations that wish to decide which model or standard to adopt. 


\section{Introduction and Overview}

This report compares and contrasts two important bodies of knowledge - the International Standard Organization (ISO) 9000 family of quality management systems standards and the Version 1.2 Capability Maturity Model ${ }^{\circledR}$ Integration (CMMI) ${ }^{\circledR}$ Development constellation. This introduction provides a background for understanding the material in this report by establishing context and providing guidance for the several potential audiences of this report. The report's primary focus is on the primary documents ISO 9001:2000 and the CMMI for Development (CMMI-DEV), V1.2 model; however, it is important to understand that both of these primary documents are supported by a number of secondary documents and sources of information.

For the purposes of this report, the term body of knowledge will be used to refer in a generic way to not only the principal document (i.e., ISO 9001:2000 or CMMI-DEV, V1.2), but also associated documents and other artifacts. In the case of ISO 9001:2000, there are a number of related standards that not only supplement the primary standard (such as ISO 9000:2005, ISO 9004:2000, and others), but also are relevant to the application or usage of ISO 9001:2000 (such as ISO 10014:2006 and ISO 10017:2003). As a result, when the phrases ISO 9001 body of knowledge or ISO 9000 family are used in this report, they refer to all of the documents mentioned above, as well as some others. (See Appendices $\mathrm{C}$ and $\mathrm{F}$ for more details.) Alternately, when the phrase CMMI-DEV body of knowledge is used in this report, it refers to multiple documents relating to CMMI-DEV, V1.2 and its application. (See Appendices B and F for more details.)

\subsection{Background}

Ever since the 1992 release of the Capability Maturity Model ${ }^{\circledR}$ (CMM) framework for Software, many organizations that produce or develop products have a greater reason to consider ISO 9001 standards as well as those of various other capability maturity models [Paulk 1994]. Over time, the uptake of these bodies of knowledge by organizations seeking both market advantage and internal process improvement has continued to rise. One recent survey showed that the three most commonly used technology standards are ISO 9001, CMMs, and ITIL, in that order [Violino 2005].

In 1994, the SEI published a technical report that addressed the relationships between ISO 9001 and the Capability Maturity Model for Software [Paulk 1994]. The present report can be viewed as a successor to that earlier report, with a focus on ISO 9001:2000 and CMMI-DEV, V1.2.

\subsection{Structure of this Report}

This report is organized into four basic sections. The first (this section) provides a brief overview of the report's focus and organization. The next two sections describe the two bodies of

๑ Carnegie Mellon, Capability Maturity Model, and CMMI are registered in the U.S. Patent and Trademark Office by Carnegie Mellon University. 
knowledge - the world of ISO 9000 and the world of CMMI-DEV. The final section provides a comparative analysis of the two bodies of knowledge. Finally, six appendices have been included to provide further information and facilitate understanding, as well as to guide the reader to additional important source materials.

\subsection{Guidance for Specific Audiences}

Individuals already familiar with one or the other of the two bodies of knowledge may find it most useful to skip to the chapter addressing the area with which they are already familiar. Once this material has been understood, the chapter comparing and contrasting the two bodies of knowledge will be more meaningful to the reader.

Those already familiar with the ISO 9000 family might already speculate as to how it relates to CMMI-DEV, and may have questions such as the following:

- My company is compliant to ISO 9001-what is the implication for the extent to which we satisfy CMMI-DEV requirements?

- Should I implement CMMI-DEV independently of ISO 9001, or are there some areas where they overlap?

- Are there aspects of the CMMI Development constellation that are inconsistent with my implementation of ISO 9001?

- Can my ISO auditor conduct appraisals based on CMMI-DEV?

- Can my ISO auditor use the work of others involved in appraisals based on CMMI-DEV?

Similarly, those already familiar with the CMMI Development constellation might already speculate as to how it relates to ISO 9001, and have questions such as the following:

- My company is CMMI-DEV maturity level 3-what is the implication for the extent to which we satisfy ISO 9001 requirements?

- Should I implement ISO 9001 independently of the CMMI Development constellation or are there some areas where they overlap?

- $\quad$ Are there aspects of ISO 9001 that are inconsistent with my implementation of the CMMI Development constellation?

- Can my SCAMPI Lead Appraiser ${ }^{\mathrm{SM}}$ conduct ISO audits?

- Can my SCAMPI Lead Appraiser use the work of others involved in ISO audits?

This report is intended to provide the beginning of a basis for addressing these and other related questions.

SM SCAMPI Lead Appraiser is a service mark of Carnegie Mellon University. 


\section{Overview of the CMMI Development Constellation}

\subsection{Scope of Application and Purpose}

The CMMI Development constellation provides a set of best practices that are structured around the concept of a capability maturity model for organizations that develop products and services and a set of appraisal methods and training courses that accompany the model. The CMMI for Development, V1.2 (CMMI-DEV, V1.2) model is intended to provide best practices for organizations striving to improve their product development capabilities. These best practices contained within the model are applicable to the development of products that contain one or more of the following elements - hardware, software, firmware, or people.

\subsection{Background}

Preparatory work began on the CMMI Product Suite in 1997, and the CMMI Product Development Team began operating in early 1998. Their work culminated in the release of version 1.0 in early 2001, followed by the release of version 1.1 in early 2002 . The current version (1.2) was released in August 2006. The V1.1 CMMI Product Development Team was composed of 135 experts from 37 organizations representing seven countries; however, these numbers do not include additional experts or individuals from other organizations or countries who contributed their expertise.

The CMMI project was formed to improve the usability of Capability Maturity Model (CMM) technology for a set of disciplines that not only include software engineering, but also extend beyond it. As the CMMI concept was initially developed, the scope of the project was restricted to a few disciplines that were most needed by government and industry.

The selection of software engineering, systems engineering, software acquisition, and integrated product development CMMs was made by industry and government participants for the initial proof-of-concept phase. However, the product suite was designed to accommodate expansion of its discipline coverage as well as product and project life-cycle coverage.

In August 2006, version 1.2 of the CMMI Product Suite was released. Among the changes was a renaming of the CMMI model to the CMMI for Development, V1.2 model. This change accommodated the anticipated expansion of CMMI practices to additional areas of interest (each new collection of related models, appraisal materials, and training materials for an area of interest was referred to as a constellation). The two new areas of interest were acquisition and services; the Acquisition constellation was published in November 2007 [CMMI Product Team 2007] and the Services constellation will be published in March 2009. Of course, the CMMI-DEV, V1.2 model and its accompanying appraisal and training material was called the Development constellation. Additional information about these other constellations is available on the SEI website. 


\subsection{Foundational Concepts and Terminology}

\subsubsection{Constellation}

A CMMI constellation is a collection of components that are used to construct CMMI models, training materials, and appraisal materials in an area of interest (e.g., development, services, acquisition).

\subsubsection{Process Areas}

Process areas (PAs) constitute the primary structural element of a CMMI model. A process area is composed of best practices that, when implemented, result in satisfaction of associated goals for that process area. Process areas have a common structure that includes required, expected, and informative components, which collectively are essential to understanding the intent of the process area and for proper implementation within a specific organizational context.

\subsubsection{Maturity Levels}

There are five maturity levels associated with the CMMI-DEV, V1.2 model, each of which represents a plateau of organizational capability. In the case of the CMMI-DEV, V1.2 model, this plateau of organizational capability is relevant for developing products. These plateaus range from maturity level 1 - the starting point of the maturity scale, representing organizations that are primarily ad hoc and chaotic in their engineering approach - to maturity level 5, which is the most sophisticated level of engineering discipline. An organization at maturity level 5 has developed the infrastructure to sustain continuing improvement by using quantitative and statistical techniques for introducing changes in an orderly and intentional way.

\subsubsection{Capability Levels}

There are six capability levels associated with the continuous representation (see the definition of this term in Section 2.5) of the CMMI-DEV, V1.2 model, each of which represents a plateau of capability associated with a particular process area. The lowest is capability level 0 , which is the starting point of the capability scale. It represents the state of implementation of a process area where one or more of the specific goals of the process area are not yet satisfied. The highest is capability level 5, the most sophisticated level of operation for a process area. An organization at capability level 5 has the infrastructure to sustain continuing improvement by using quantitative and statistical techniques for introducing changes in an orderly and intentional way in that process area.

\subsubsection{Appraisal}

An appraisal is the examination of product development processes by a trained team of engineering professionals. The team uses a process reference model (such as the CMMI-DEV, V1.2 model) as the reference point for identifying process strengths and weaknesses. 


\subsubsection{Appraisal Team}

The appraisal team is comprised of professionals who are trained in an appraisal methodology. The team collects and reviews objective evidence and uses it to determine the extent of an organization's practice implementation. This provides the basis for determining process strengths and weaknesses and, potentially, goal ratings.

\subsubsection{Appraisal Requirements for CMMI (ARC)}

The appraisal requirements for CMMI (ARC) define the set of requirements applicable to those appraisal methods that are used in conjunction with CMMI models. The ARC document was developed by the CMMI Product Development Team and is considered to be an integral part of the CMMI Product Suite. See also "SCAMPI Family," which is described below.

\subsubsection{Standard CMMI Appraisal Method for Process Improvement (SCAMPI)}

The Standard CMMI Appraisal Method for Process Improvement (SCAMPI) is the ARC class A appraisal method chartered by the CMMI Steering Group and developed by the CMMI Product Development Team. SCAMPI is intended to be the appraisal mechanism by which all capability or maturity level ratings are derived. See also "SCAMPI Family," which is described below.

\subsubsection{SCAMPI (A, B, C) Family}

Three appraisal methods constitute the SCAMPI family-SCAMPI A, SCAMPI B, and SCAMPI

C. Each of these appraisal methods satisfies, respectively, the ARC criteria for a Class A, B, or C appraisal method. These three are designed to be an integrated set of methods that can be used as part of a process improvement strategy by organizations seeking to increase their product development capabilities.

\subsubsection{SCAMPI Lead Appraiser}

A SCAMPI Lead Appraiser is an individual who has demonstrated the required skills and knowledge to be granted the authorization to lead appraisals in the SCAMPI family. The SCAMPI Lead Appraiser is responsible for ensuring that the appraisal is planned and executed in accordance with the provisions of the SCAMPI appraisal method.

\subsubsection{Institutionalization}

Institutionalization is the ingrained way of doing business that an organization routinely follows as part of its corporate culture and practices. The process is ingrained into the way the work is performed and there is commitment to and consistency in performing the process. The CMMI generic practices describe activities that address these aspects of institutionalization, and there is a clear progression of process institutionalization throughout these generic practices. 


\subsubsection{Representation}

Representation refers to the organization, use, and presentation of the components of a CMM. Two types of approaches to presenting best practices are generally evident: the staged representation and the continuous representation.

\subsection{Key Product Elements}

The key components of the CMMI Product Suite are the models, appraisal methods (e.g., the SCAMPI family), and training courses. These are addressed in more detail in later sections.

\section{$2.5 \quad$ CMMI Models}

CMMI models are part of the CMMI Product Suite and each CMMI constellation. They are the official documents that contain CMMI best practices and are freely available for download on the SEI website. In addition to the models themselves, the SEI website provides an extensive set of supplementary material, including release notes, errata, and comparisons to related CMMI models.

The CMMI-DEV, V1.2 model can be viewed from two perspectives (called representations) known as the continuous representation and the staged representation. The continuous representation is expressed from the perspective of a set of processes, each of which can be evaluated in terms of process capability as per ISO/IEC 15504 [ISO/IEC 2003]. The staged representation is expressed from the perspective of the traditional five-stage organizational maturity scale developed by the SEI and first described in an SEI technical report authored by Watts Humphrey in 1987 [Humphrey 1987]. In 2007, an additional model was released (CMMI for Acquisition, V1.2), but this technical report focuses only on CMMI-DEV, V1.2.

In addition to the CMMI for Acquisition model (published in 2006), the CMMI for Acquisition Primer also defines effective and efficient practices for acquisition projects [Richter 2008]. The primer is consistent with the practices in the model and is a smaller document that can be used by acquisition organizations.

A model for service organizations (CMMI for Services) has also been developed, and the initial version of this model was published in February 2009. CMMI has been designed to facilitate the expansion to additional disciplines over time, and as a result, the community may expect a broadening in the scope of CMMI models in the future.

\subsection{Appraisal}

The requirements for CMMI appraisal methods are established in the Appraisal Requirements for CMMI, also known as the ARC [SCAMPI Upgrade Team 2006a]. The ARC also establishes three classes of CMMI appraisal methods: ARC Class A, ARC Class B, and ARC Class C.

An integrated and upwardly compatible family of CMMI appraisal methods is an integral part of the CMMI Product Suite. These appraisal methods are suitable for a wide range of appraisal needs, and can also be customized based on the needs of the customer organization. The SCAMPI family of appraisal methods (SCAMPI A, SCAMPI B, and SCAMPI C) is modeled after the 
classification schema for CMMI appraisal methods defined in the ARC. The scope of application is broad - it ranges from quick-look style appraisals all the way to benchmarking quality appraisals. The SCAMPI family architecture differentiates three classes of methods by identifying the primary focus of SCAMPI A, B, and C as "institutionalization," "deployment," and "approach," respectively.

The SCAMPI A appraisal method is defined in the SCAMPI Method Definition Document (SCAMPI MDD), and is supported by a library of artifacts that are made available to SCAMPI Lead Appraisers [SCAMPI Upgrade Team 2006b]. The SCAMPI B and SCAMPI C methods are defined in the Handbook for Conducting Standard CMMI Appraisal Method for Process Improvement (SCAMPI) B and C Appraisals [Hayes 2005].

The SCAMPI A appraisal method is the only member of the SCAMPI family that can result in capability or maturity level ratings). SCAMPI A was conceived and designed to have benchmarking-level quality and to become the standard method within the CMMI community for establishing capability or maturity level ratings. More information about the SCAMPI A appraisal method is available on the SEI website.

SCAMPI A appraisals are led by an authorized SCAMPI Lead Appraiser who is assisted by qualified team members chosen and trained with care, mostly from the evaluated organization. The examination of the organization consists of a preparation phase, an on-site phase, and a reporting phase. The appraisal findings are presented to the appraisal sponsor as goal-level statements that summarize the gaps in practice implementation. The SCAMPI Lead Appraiser provides a required report to the SEI. Finally, if the Lead Appraiser makes the request, and the appraised organization authorizes the SEI to do so, the SEI publishes a subset of the appraisal results on the published appraisal results page on the SEI website.

\section{7 $\quad$ Training}

The SEI provides a comprehensive set of training courses relating to the CMMI Product Suite. The prerequisites for these courses vary for each course. Some of these courses are also available from SEI Partners - these are indicated by asterisks $\left(^{*}\right)$.

The CMMI curriculum can be structured into the following areas:

- Overview courses

- CMMI-Based Process Improvement Overview [SEI 2009a]

- Model competency

- Introduction to CMMI, Version 1.2* [SEI 2009b]

- Intermediate Concepts of CMMI, Version 1.2 [SEI 2009c]

- $\quad$ Train-the-trainer

- CMMI Version 1.2 Instructor Training [SEI 2009d]

(also see appraisal team leader courses below)

- Process appraisal

- $\quad$ SCAMPI B and C Team Leader Training [SEI 2009e]

- SCAMPI Lead Appraiser Training* [SEI 2009f] 
- SCAMPI Version 1.2 Class A Team Training* [SEI 2009g]

- SCAMPI Version 1.2 Class B Team Training* [SEI 2009h]

- SCAMPI Version 1.2 Class C Team Training* [SEI 2009i]

- $\quad$ Special application topics

- Implementing Goal-Driven Measurements* [SEI 2009j]

- Analyzing Project Management Indicators [SEI 2009k]

- Advanced topics

- Understanding CMMI High Maturity Practices [SEI 20091]

- Improving Process Performance Using Six Sigma* [SEI 2009m]

- Designing Products and Processes Using Six Sigma* [SEI 2009n]

- In addition, the following SEI courses are directly relevant to individuals responsible for process improvement initiatives:

- Mastering Process Improvement [SEI 2009o]

- Consulting Skills Workshop* [SEI 2009p]

- Managing Technological Change* [SEI 2009q]

\subsection{Supporting infrastructure}

The supporting infrastructure consists of several sponsoring organizations, a Steering Group composed of government, industry, and SEI members, SEI Partners (organizations licensed by the SEI to provide CMMI-related services), and a steward organization, which collectively provide a source of sustainment and continuing support for the adoption and continuing improvement and evolution of the CMMI Product Suite.

This infrastructure is illustrated in Figure 1. For an explanation of the acronyms in Figure 1, see Appendix D.

The SEI maintains the following offices:

- $\quad$ SEI Pittsburgh (Main Office), Pittsburgh, PA, U.S.A

- $\quad$ SEI Colorado Springs, Colorado Springs, CO, U.S.A.

- $\quad$ SEI Europe, Frankfurt, Germany

- $\quad$ SEI Los Angeles, Los Angeles, CA, U.S.A

- $\quad$ SEI Washington, DC, Arlington, VA, U.S.A 


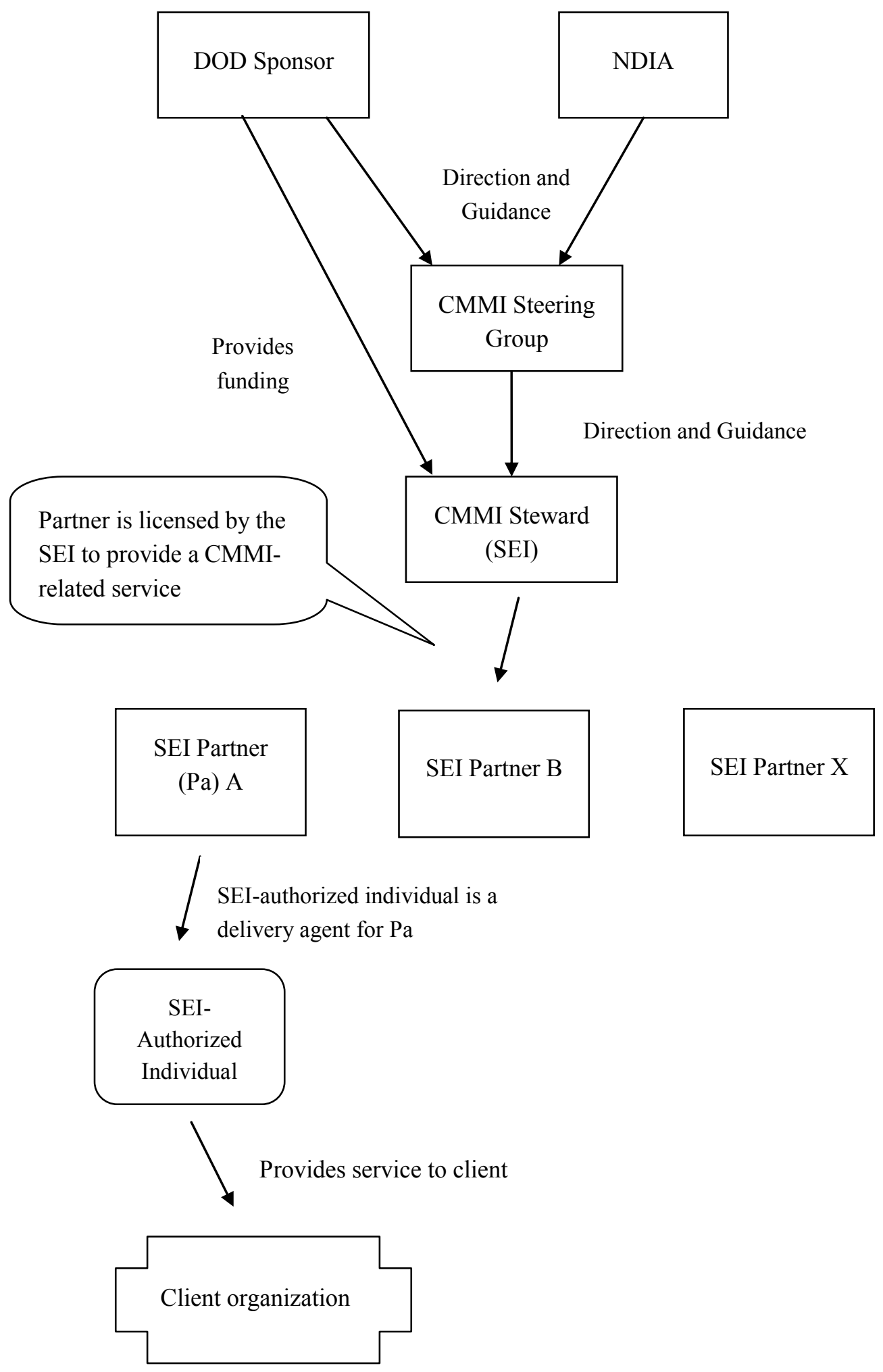

Figure 1: $\quad$ Supporting Infrastructure for CMMI 


\subsubsection{Sponsorship}

The CMMI Product Suite has a major government sponsor (U.S. Government) as well as industrial sponsorship.

Government sponsorship is provided in part by the Office of the Under Secretary of Defense for Acquisition, Technology, and Logistics (OUSD AT\&L) [OUSD 2008]. Industrial sponsorship is provided by the Systems Engineering Committee of the National Defense Industrial Association (NDIA) [NDIA 2008].

The government sponsor has established a Steering Group to direct and oversee the evolution and maintenance of the CMMI Product Suite [CMMI Steering Group 2008]. The group is composed of industry and government representatives, as well as the SEI (in its capacity as CMMI Steward).

\subsubsection{Stewardship}

The purpose of the CMMI Steward is to ensure the quality and widespread use of the CMMI Product Suite and to support its adoption throughout government and industry. In pursuit of the SEI's role as CMMI Steward, several parts of the institute make important contributions.

\subsubsection{CMMI Initiative}

The SEI's CMMI Initiative provides support for both the sustainment and evolution of the CMMI Product Suite. This initiative includes teams of professionals that focus on the components of the product suite.

It is significant that the CMMI Initiative is supported by other SEI initiatives, such as Software Engineering Measurement and Analysis (SEMA), the Personal Software Process (PSP) and the Team Software Process (TSP), as well as the Acquisition Support Program (ASP), in piloting and measuring the value and impact of CMMI adoption in the community.

\subsubsection{Product Transition and Development}

The SEI's Product Transition and Development group administers the SEI Partner Network, which, in turn, provides support for the authorization and maintenance of SCAMPI Lead Appraisers and instructors for the CMMI introductory course.

\subsubsection{SEI Credentials Program}

The SEI offers both certificate and authorization programs that pertain to the CMMI Product Suite.

Certificates are awarded to course attendees who complete a prearranged series of continuing education courses, and serve to recognize successful completion of an educational process. Participation in certificate programs is a good way to build one's skills and generally do not require testing or additional follow-up training.

Authorizations often involve ongoing requirements that must be met to keep the authorization valid. While SEI authorizations by themselves do not grant permission to use the SEI's 
intellectual property, they do signify that an individual has been authorized by the SEI as having obtained a specific set of skills and knowledge in a particular area. Authorization allows an individual to build professional credentials through the objective confirmation of relevant skills.

Certification or authorization is earned after an individual completes a prearranged series of courses and his or her knowledge is assessed against a set of industry-relevant standards.

\subsection{Adoption}

The SEI collects adoption data on a continuing basis as part of its role as steward of the CMMI

Product Suite. The information in the tables below was provided by the SEI and was current as of December 31, 2008 [SEI 2009r].

The number of individuals who have successfully completed the indicated CMMI-related training courses is indicated in Table 1:

Table 1: $\quad$ Individuals who Have Completed CMMI-Related Training Courses

\begin{tabular}{|l|c|}
\hline \multicolumn{1}{|c|}{ Training Course } & $\begin{array}{c}\text { Number of } \\
\text { Students }\end{array}$ \\
\hline Introduction to CMMI & 97,051 \\
\hline Intermediate CMMI & 2,877 \\
\hline Instructor Training for Introduction to CMMI & 678 \\
\hline Understanding CMMI High Maturity Practices & 528 \\
\hline
\end{tabular}

The number of individuals who have received authorization credentials from the SEI is indicated in Table 2:

Table 2: Individuals who Have Received SEI CMMI Authorization Credentials

\begin{tabular}{|l|c|}
\hline \multicolumn{1}{|c|}{ Authorization Credential } & $\begin{array}{c}\text { Number of } \\
\text { Students }\end{array}$ \\
\hline Introduction to CMMI V1.2 Instructors & 439 \\
\hline SCAMPI V1.2 Lead Appraiser & 497 \\
\hline SCAMPI B\&C Team Leader & 506 \\
\hline Certified v1.2 High Maturity Lead Appraisers & 149 \\
\hline
\end{tabular}


One important indicator of the extent of CMMI adoption is the number of SCAMPI A appraisals conducted and reported to the SEI. The following numbers were reported by the SEI covering the period from the release of SCAMPI V 1.1 in April 2002 through December 2008 [SEI 2009r]:

- $\quad 3,113$ appraisals

- 2,634 organizations

- 1,882 participating companies

- 361 reappraised organizations

- 14,620 projects

$67.1 \%$ are organizations outside of the U.S.A. 


\section{Overview of the ISO 9000 Family}

\subsection{Scope of Application and Purpose}

The ISO 9000 family of standards has been developed to assist organizations of all types and sizes in their implementation and operation of effective quality management systems. Many companies have benefited from ISO 9001 implementation when the scope of the "organization" was extended to the entire company or entity. In a similar fashion, quality management, when based on a systems perspective, represents the entirety of management's work in managing and improving performance. Additionally, ISO 9001 benefits have been realized when the management of quality has been extended from simply product and process quality to the application of a system of processes within an organization, together with the identification and interactions of these processes and their management. This is referred to as the ISO 9001:2000 process approach.

ISO 9001 standard is for quality management systems, and is not a

- $\quad$ product standard

- $\quad$ quality management system

- guarantee of product or service quality.

\subsection{Background}

The following is a brief history illustrating the origins of the ISO 9000 family:

- Mil-Q-9858a in 1959, quality standard for military procurement

- $\quad$ BS 9000 in 1970, quality assurance for the electronics industry

- $\quad$ BS 5750 in 1979, for manufacturing industries

- $\quad$ ISO 9001 in 1987, revised 1994, focused on manufactured products

- ISO 9001 in 2000, which added process approach and strengthened the areas of customer satisfaction and continual improvement

ISO 9001 will be amended in 2009 for improved clarity, although no additional requirements will be added.

The core of the ISO 9000 family contains three documents:

1. ISO 9000:2005 Quality management systems - Fundamentals and vocabulary

2. ISO 9001:2000 Quality management systems-Requirements

3. ISO 9004:2000 Quality management systems_-Guidelines for performance improvements 


\subsection{Foundational Concepts and Terminology}

ISO 9000 describes the eight quality management principles that form the basis for the quality management system standards and that are used by top management:

1. customer focus

2. leadership

3. involvement of people

4. process approach

5. system approach to management

6. continual improvement

7. factual approach to decision making

8. mutually beneficial supplier relationships

ISO 9001 requirements can be condensed into five key statements. The organization shall

1. determine the needs and expectations of customers and other interested parties

2. establish policies, objectives and a work environment necessary to motivate the organization to satisfy these needs

3. design, resource and manage a system of interconnected processes necessary to implement the policy and attain the objectives

4. measure and analyze the adequacy, suitability, efficiency, and effectiveness of each process in fulfilling its purpose and objectives, and

5. pursue the continual improvement of the system from an objective evaluation of its performance

\subsubsection{Quality Management System}

ISO 9000 terms and definitions include the following:

- $\quad$ quality management system (QMS): management system to direct and control an organization with regard to quality

- management system: system to establish policy and objectives and to achieve those objectives

- organization: group of people and facilities with an arrangement of responsibilities, authorities and relationships

- quality: the degree to which a set of inherent characteristics fulfils requirements

- requirement: a need or expectation that is stated, generally implied or obligatory 


\subsubsection{Accreditation}

ISO accreditation is the issuance of written assurance (the certificate) by an independent, external body that has audited an organization's management system and verified that it conforms to the requirements specified in the standard. Accreditation is similar to certification by a certification body in that it provides a formal recognition and independent confirmation of competence, but accreditation is a choice, rather than an obligation.

\subsubsection{Accreditation Body}

The accreditation body is a national authoritative organization that oversees and confirms the competency of third-party certifiers; this body also follows the requirements established by the International Accreditation Forum. ANSI-ASQ National Accreditation Board (ANAB) is the U.S. accreditation body. ANAB accredits certification bodies (CBs) for ISO 9001 quality management systems.

\subsubsection{Certification}

ISO certification refers to the issuing of written assurance (the certificate) by an independent, external body that has audited an organization's management system and verified that it conforms to the requirements specified in the standard.

Certification seems to be the term most widely used worldwide, although registration (and registrar as an alternative to certification body) is often preferred in North America. Certification and registration are also used interchangeably.

\subsubsection{Certification Body}

The certification body is an organization of certified auditors, in conformance with ISO/TR 17021, which provides an independent third-party audit of an organization seeking certification against a standard. Note that certification bodies will tend to recommend that companies use ISO 9001 to achieve their business objectives.

\subsubsection{Registration}

ISO registration refers to the auditing body's recording of the certification in its client register.

Certification seems to be the term most widely used worldwide, although registration (and registrar as an alternative to certification body) is often preferred in North America. Certification and registration are also used interchangeably.

\subsubsection{Registrar}

The registrar is the same as the certification body.

\subsubsection{Auditor}

An auditor is a person who conducts audits, after demonstrating the competence to do so. 


\subsubsection{Audit}

An audit is the systematic, independent, and documented process for obtaining audit evidence and evaluating it objectively to determine the extent to which audit criteria are fulfilled.

\subsubsection{Audit Evidence}

Audit evidence consists of records, statements of fact, or other information that is verifiable and relevant to the audit criteria.

\subsubsection{Audit Criteria}

Audit criteria consist of a set of policies, procedures, or requirements that are used as a reference.

\subsubsection{Competence}

Competence is the demonstrated ability to apply knowledge and skills.

\subsubsection{Certified Competence}

Auditor competence is normally certified by a certification body (such as RABQSA International) that is conforming to ISO/TR 17024. In this way, the auditor achieves certified competence.

\subsection{Key Product Elements}

The key components of the ISO 9000 family are the definitions, requirements, performance improvements guidance, and auditing requirements. Audit training providers are certified by national bodies.

\subsubsection{Process Scope}

ISO 9001 QMS Requirements cover all key business processes (e.g., product development and delivery, or service delivery) that affect the organization's ability or responsibility to provide a product that meets customer requirements and all applicable regulatory requirements. ISO 9001 is the most "popular" document (i.e., has sold the largest number of copies) of the ISO 9000 family, and is sold by national bodies, such as ANSI or ASQ in the U.S and the British Standards Institute (BSI) in the UK. ISO 9001 has become the foundation of several industry sector standards such as aerospace (AS 9100), telecom (TL 9000), automobile (ISO TS 16949), chemical (RC 14001), medical devices (ISO 13485), and petroleum and natural gas (ISO/TS 29001). These individual industry standards require additional training and/or experience for the lead auditors. However, the primary focus of this report is on ISO 9001 and not on sector variants.

ISO 9001 audits (discussed in detail below) are conducted against a defined scope of approval that has been formulated jointly between the organization and lead auditor. The scope of approval is a very important aspect of the ISO 9001 audit and must clearly identify the product or service that the organization is offering for assessment, along with any limitations of the product being assessed, as well as any supporting activities necessary for producing or maintaining the product. 
The organizational scope of sites and departments to be included in the audit are defined in advance of the audit, as well as an audit scope of the ISO 9001 clauses to be verified as implemented by the organization in scope of the audit. Where a subset of the organization is the organization scope, all other interfacing parts of the organization are treated as outsourced parts of the QMS, controlled by ISO 9001 clause 4.1, and managed as suppliers under the ISO 9001 clause 7.4. The scope of the audit is controlled by ISO 9001 clause 1.2 that defines what parts of the ISO 9001 clauses may be "excluded" from the audit scope. If a requirement described by an ISO 9001 clause is actually performed within the scope of the organization or an outsourced entity, it must be included in the audit scope. The organization scope and the audit scope are the basis for the Registrar's quote for services and how many auditors are assigned to the audit.

These rules are intended to ensure that the final certificate of approval does not mislead potential stakeholders; for example, customers of the organization. It must be noted, however, that activities that are an inherent part of the organization's line of business or that are required by the ISO 9001 standard cannot be excluded from the scope of approval.

In addition to the scope of approval, the lead auditor will also need to establish the locations at which these activities are either undertaken or are supported within the organization. Once certain other requirements, such as the size of the organization, geographic aspects, or working patterns have been identified, the lead auditor will be in a position to prepare a plan for the audit.

In practice, organizations will define the product or service, the locations involved, and the limitations that are subject to the scope of approval (or certification). Apart from clauses identified within Section 7 of the ISO 9001 standard, all clauses are applicable, and the organization under certification must demonstrate adherence to their specifications in relation to the defined scope of approval.

The clauses in Section 7 can be deemed not applicable, but the rationale for this judgment within the organization scope must be defined as an exclusion (per clause 1.2 in the organization's Quality Manual), and agreed upon by the certification body. As described above, clause requirements are sometimes fulfilled by a subset of the organization outside the audited organization scope. These other interfacing parts of the organization (or external contractors) are treated as outsourced parts of the QMS, controlled by ISO 9001 clause 4.1, and managed as suppliers under the ISO 9001 clause 7.4.

\subsubsection{Sector-Specific Variants}

There are a number of sector-specific variants and guides associated with ISO 9001, with the Tick IT guide probably being one of those that relate most closely with the CMM for Software (previously) and now with CMMI-DEV, V1.2. Associated standards and guides include ISO 9000-3 (now superseded by ISO 90003), which provides interpretation of the ISO 9001 requirements for the IT sector. It must be noted, however, that this is not an assessable standard. ISO 90003 assists stakeholders, such as quality managers or auditors, in translating the generic terms used in ISO 9001 into terms that are commonly understood in the IT industry. 
The Tick IT guide elaborates, in a detailed and informative manner, on ISO 90003's more general translation of ISO 9001 into terms commonly understood in the IT industry. Supporting the Tick IT guide is the Tick IT scheme, which is currently recognized by the UK and Swedish accreditation bodies. Organizations can adopt the Tick IT scheme and will, if judged acceptable by the Tick IT auditor, be awarded an accredited certificate bearing the Tick IT logo in addition to the accreditation body logo. The Tick IT scheme principally requires that organizations, primarily in the IT sector, implement and demonstrate a quality management system that satisfies the ISO 9001 requirements, as guided by the Tick IT guide and audited by Tick IT Lead Auditors.

The Tick IT guide is a required input to the auditing and certification process when a Tick IT certification is being sought. As with all other ISO 9001-based industry sector schemes, an organization may achieve ISO 9001 certification — but not the sector scheme's certification - if the sector scheme's required elaborations on ISO 9001 have not been demonstrated in the audit. The interpretation and guidance is intended to help IT organizations understand and implement processes, procedures, and practices that satisfy the ISO 9001 requirements. As a simple example, clause 7.5.1 of ISO 9001:2000 requires that Product Identification and Traceability be implemented and demonstrated, and the Tick IT guide helps to explain how Configuration Management would address this ISO 9001 requirement.

Tick IT is a scheme for certification in the Information Technology sector sponsored by the UK government. A Certification Body must be accredited by UKAS to certify this scheme.

The current list of sector-specific documents can be found in TC176 N881. [ISO 2006b] A list of registrars can be found at http://www.iso.org/iso/en/info/ISODirectory/countries.html.

\subsection{Appraisal}

In ISO 9001, an appraisal is called an audit (see the above definition). The audit is conducted using ISO 19011, or QE19011S within the U.S., for internal quality auditors. Conformance to ISO 9001 is rated as either pass or fail. While ISO 9001 has a maturity scheme in ISO 9004 Appendix A, it is informative and does not affect ISO 9001 registration audits. ISO 9001 audit results are recorded in the final audit report for registration, and findings that affect registration are recorded as non-conformances, typically as either minor or major.

In the case of a minor non-conformance (in the spirit of continual improvement) and following an exchange of correspondence concerning the corrective action planned or taken by the audited organization, a certificate indicating certification is issued, the audited company is registered as conforming to ISO 9001 standards, and the actual corrective action taken is verified as effective at the next surveillance audit of the audited organization. This may occur as rapidly as the audited organization can respond to the minor audit findings, and the Lead Auditor confirms the suitability of the action recorded in the correspondence from the audited organization.

In the case of a major non-conformance (once again, in the spirit of continual improvement) following an exchange of correspondence on the corrective action that is actually taken by the audited organization, a follow-up audit on only the major non-conformance is performed to verify effective implementation. Once effective implementation is verified, a certificate indicating certification is issued, and the company is registered as conforming to ISO 9001 standards. 
ISO 9001 audits can be conducted internally, as required by clause 7.4.1; by a second party, such as the organization's customer, for the purpose of contract conformance; or by an independent third party, called a certification body, for the purpose of achieving a certification.

In ISO 9001 terms, organizations undergo audits conducted by one or more auditors led by a lead auditor. The audit process consists of a number of activities, some mandatory and some optional, but almost always in a defined order. The first activity, which is optional, might be for the organization to request a preliminary audit, which is conducted by the lead auditor. The preliminary audit includes a document review (called the adequacy audit) to ensure that the organization has an adequate framework against which an audit can be conducted. A preliminary audit is used by the organization to get a feel for the areas of weakness or concern prior to any formal audit activities. The approach may range from conducting a broad high-level check of the processes across a wide range of business areas to a very detailed check on activities undertaken in specific parts of the business. The result of the preliminary audit is usually a report by the lead auditor that highlights any aspects that might cause a problem which would prevent certification during a formal certification audit.

The next stage of the audit process, which is mandatory, is to conduct the stage 1 audit, which is better known as the documentation review [ISO 2004]. This audit is intended primarily for scoping and planning a certification audit (the stage 2 audit) and to allow the auditor to obtain a more thorough understanding of the organization. The auditor examines the quality management system documentation to ensure that the organization has defined processes and procedures that will address the requirements of the ISO 9001 standard. The rationale for this audit is that if the organization's defined system does not address the requirements, there is a high risk that its practices are insufficient as well. This won't always be the case, but since defined processes are required, it can be more cost effective to start with those than to conduct a full audit to determine that the practice is deficient because defined processes are absent.

In addition to examining the defined management system, the lead auditor will check the implementation of some aspects of the standard, specifically that management commitment is present and that the plan-do-check-act cycle is either well underway or has iterated at least once. One of the fundamental aspects of the ISO 9001:2000 standard is the concept of plan-do-checkact; in order to successfully achieve ISO 9001:2000 certification the organization must demonstrate its following of this cycle. In addition to checking process documentation, the lead auditor schedules interviews with senior management to check management commitment, investigate management reviews, examine internal audit records, and understand process measures and analysis.

The result of the stage 1 audit is a report that defines areas of concern, which are usually expressed as deficient areas, including comments, and observations. The lead auditor usually also indicates whether the defined time scales for conducting the main (stage 2) audit are practical and appropriate.

Usually within three to six months, and assuming that no major issues or concerns were raised at the stage 1 audit, the stage 2 compliance audit is undertaken. This is the main mandatory part of the audit, in which evidence is gathered and consolidated to demonstrate that the defined and 
planned arrangements are being effectively implemented. The schedule usually involves an opening meeting, audit activities, a team meeting, and a closing meeting. The most popular audit approach is to conduct interviews with key members of staff and, where appropriate, to witness activities being performed. Additionally, evidence presented at the time of the interviews is examined to confirm the statements that were made.

The result of a stage 2 audit is usually a report that contains details of the audit, including comments, observations, and non-conformances. Additionally, if the organization is compliant with the requirements of ISO 9001:2000, a recommendation for approval will also be made. In most cases, a recommendation for approval will only be made when there are zero nonconformances.

The certification body conducts a technical review of the recommendation, and if it is deemed acceptable, a certificate of approval will be raised. The certificate identifies the details of the organization being audited, the scope of approval, the locations where the scope of approval applies, and the certificate's expiration date (which is usually three years from the issue date).

Once successful, the organization is required to undergo a series of surveillance visits over the certification period - usually, a visit by an auditor every six months for three years, after which time, a recertification is performed. There is an accepted variance to this for small firms, wherein the surveillance period is extended to nine months in the same certification period. These surveillance visits do not involve re-examination of entire system but only of sample elements, in order to provide some degree of confidence that the system continues to be implemented effectively. However, certain key aspects are almost always checked, including management commitment, system changes, management reviews, internal audits, handling customer complaints, corrective and preventative actions, measurements, and continuous improvements.

The last surveillance visit is replaced by a recertification visit, during which the whole system is rechecked. If this recheck indicates that the organization remains in compliance, the certificate is extended for an additional three years.

Throughout the certification period, an organization can request changes to approval to extend the scope of certification. The certification body analyzes such requests and ensures that adequately skilled auditors and audit time are included in the surveillance visit, or that an additional visit is included to address the request. The same approach used in the initial audit is implemented on a much smaller scale to address the change to approval. If the audit is successful, the certificate will be updated and reissued, although the three-year certification period will not be extended. 


\subsection{Training}

Training providers are third parties who are certified by bodies such as RABQSA International, which is accredited by the International Standard for Personnel Certification, ISO/IEC 17024:2003. RABQSA has the ability to design, develop, and manage personnel certification schemes. Its courses are used by over 50 training companies, and its ISO 9001 specific courses are

- RABQSA-AU—Auditing Management Systems

- RABQSA-TL—Leading MS Audit Teams

- RABQSA-QM-Quality Management Systems

The audiences for these courses are

- provisional auditors

- $\quad$ auditors

- principal auditors

- lead auditors

- business improvement auditors

Another certification body is the International Register of Certified Auditors (IRCA) in the UK. 


\subsection{Supporting infrastructure}

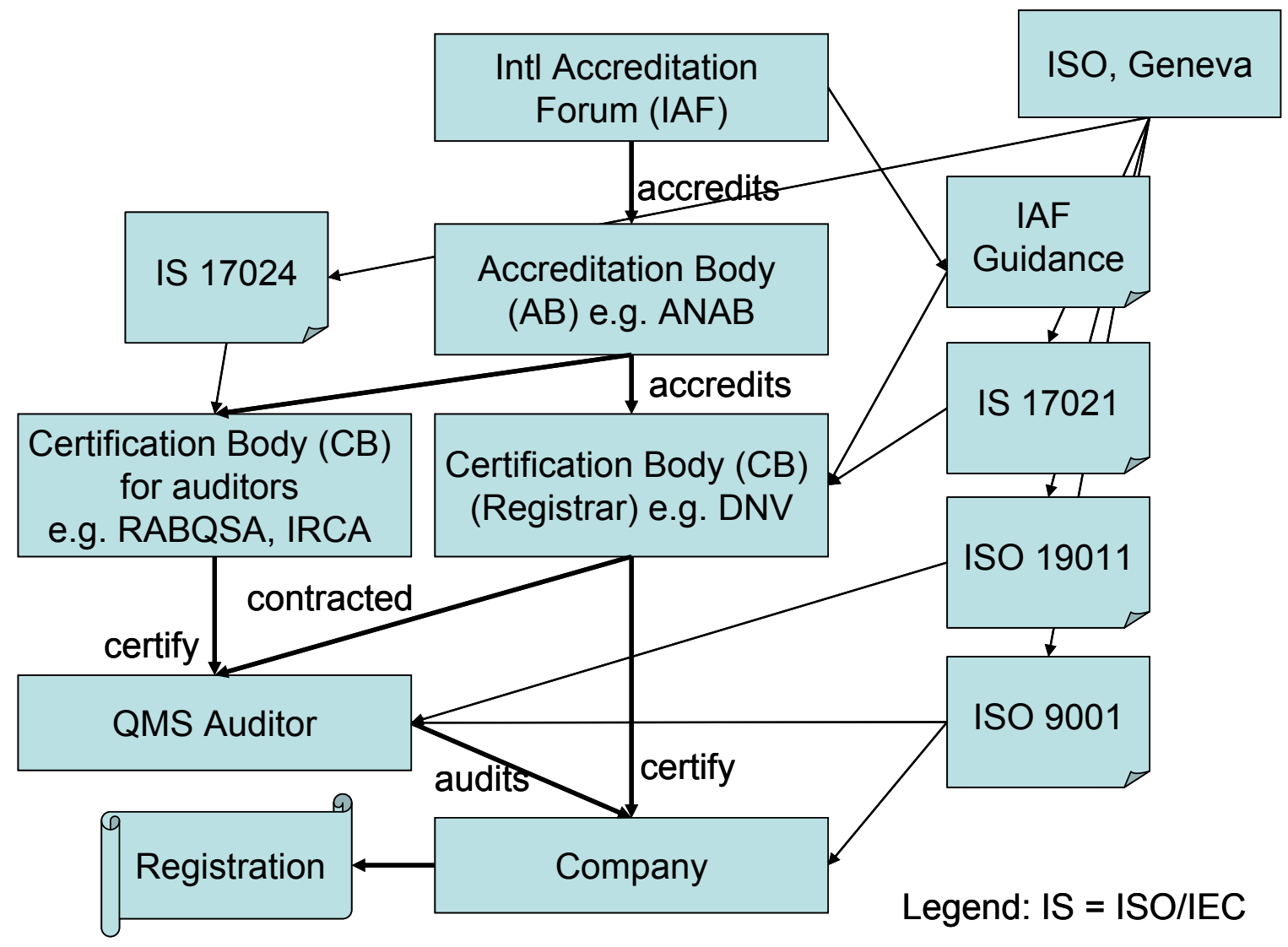

Figure 2: $\quad$ Supporting Infrastructure for ISO 9001

\subsection{Adoption}

By the end of 2005, 776,608 ISO 9001 certificates had been issued in 161 countries and economies, and many more companies have self-declared conformance to ISO 9001 standards. Software engineering companies have used ISO/IEC 90003 for guidance on applying software to ISO 9001 . 


\section{Comparative Analysis}

In this section, we examine the differences between the ISO 9000 framework and the CMMIDEV, V1.2 model. The purpose is not to suggest that one approach is superior to another, but to help readers understand and appreciate each model's differences, and to see how these differences are driven by both the original and the evolved purposes of each model or framework. Since many readers of this report "live" in one or the other bodies of knowledge, we hope that discussing the bodies of knowledge in this way will facilitate a deeper understanding and appreciation for the other.

\subsection{Terminology}

Appendix E identifies important terms that the two models have in common, but for which the terms or definitions are not identical.

The foremost of these differences between the two models are the fundamental evaluation criteria, which are suggested by the use of the terms "audit" and "appraisal." As it happens, these terms do connote some important differences between the two approaches.

The above terms are closely associated with the notions of "certification" and "authorization." The term certification is used in the ISO 9000 family to mean that a credential (the certificate) has been awarded to the organization, and that both the certification body and the auditor certify that the audit report documents the scope of the organization and the scope of the audit, as well as identifying any non-conformances.

The Registrar records subsequent client corrective actions that are accepted by the Registrar, and notes the basis for the decision (which is only within the process bounds reflected by the audit evidence sampled as recorded in the auditor's audit notes on file with the Registrar).

The ISO scheme also provides for certification of individuals. Figure 2 in Section 2.8 shows that the certification body for auditors certifies ISO 9001 auditors.

In CMMI, the single closest equivalent to the ISO 9001 certification certificate is the SEI Appraisal Disclosure Statement (ADS) - a required part of the SCAMPI Lead Appraiser's report to the SEI - that is reviewed and approved by the SEI. This is a similar process to ISO 9001, where the Registrar Certification Department approves the audit report, client response to nonconformances and auditor acceptance, the audit scope, and the certificate. Also, this department typically records the client's Registration in the Registrar's Directory.

In the CMMI world, there is no single equivalent to certification. One would say that an organization has achieved a designated maturity level and that after following an internal quality review process, the SEI has accepted the appraisal as valid. The term authorization is sometimes confused with certification by those impacted by CMMI-based improvement - in fact, the two terms are only loosely associated with one another. Authorization has a well-defined meaning in the CMMI world - it means that an individual has successfully fulfilled SEI requirements related to a subject matter area and has demonstrated the skills requisite to being granted permission by 
the SEI to deliver a particular service on behalf of an SEI Partner. For example, an individual who has been authorized by the SEI as a SCAMPI Lead Appraiser or a High Maturity Lead Appraiser is allowed to use SEI materials to lead a SCAMPI A appraisal, as long as it is conducted under the auspices of an SEI Partner that has a license for that service.

\subsection{Key Product Elements}

As an international standard, ISO 9001 is composed of several kinds of informational elements that are broadly classified into two types - normative and informative. For the purposes of comparison with CMMI-DEV, the normative element called requirement is closest in meaning to the "required" category of information in CMMI-DEV, V1.2 - that is, goal statements. In ISO 9001, requirements are expressions in the standard conveying criteria to be fulfilled if compliance with the standard is to be claimed and from which no deviation is permitted. There are strict style rules for the expression of ISO requirements - they contain the word "shall" or the phrase "shall not."

Similarly, the normative element called recommendation is closest in meaning to the "expected" category of information in CMMI-DEV, V1.2 - which comprises practice statements. In ISO 9001, a recommendation is an expression conveying that among several possibilities one is regarded as particularly suitable, without mentioning or excluding others; or that a certain course of action is preferred (but not necessarily required), or that (in the negative form) a certain possibility or course of action is deprecated, but not prohibited. A recommendation would contain the words "should" or "should not."

Finally, all other informational elements in ISO 9001 would correspond to what is referred to in CMMI as informative material.

ISO 9001, like CMMI, has a maturity scheme in Appendix A of ISO 9004; however, it is guidance material and it has rarely been used in practice. The maturity scheme in CMMI plays a more central role to the CMMI community than the ISO 9001 maturity scheme does to the ISO 9001 community.

\subsection{Process scope}

\subsubsection{Organizational Scope}

ISO 9001 functions as a generic standard for all organizations and thus is written at a high level (only 19 pages). The scope of ISO 9001 is broader than that of CMMI-DEV, V1.2, as it may be applied to part of an organization, or to all aspects of the organization that are, in principle, encompassed by the provisions of ISO 9001. 


\subsubsection{Level 1 Coverage Comparison}

The following table shows a summary comparison of the content relationships between the major clauses of ISO 9001 and the CMMI-DEV, V1.2 process categories. A green cell indicates a significant or notable amount of overlap, while a grey cell indicates minimal or no content overlap. We call this a level 1 mapping to indicate that it reflects high-level relationships that are relative to the fundamental architectural components of the two bodies of knowledge.

Table 3: $\quad$ Summary Comparison of the Content Relationships Between the Major Clauses of ISO 9001 and the CMMI-DEV, V1.2 Process Categories

\begin{tabular}{|c|c|c|c|c|c|}
\hline & 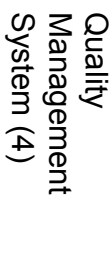 & 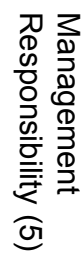 & 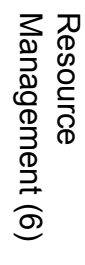 & 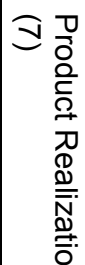 & 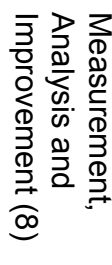 \\
\hline \multicolumn{6}{|l|}{$\begin{array}{l}\text { Process } \\
\text { management }\end{array}$} \\
\hline \multicolumn{6}{|l|}{$\begin{array}{l}\text { Project } \\
\text { management }\end{array}$} \\
\hline \multicolumn{6}{|l|}{ Engineering } \\
\hline Support & & & & & \\
\hline
\end{tabular}


The following table shows a more detailed comparison of how the generic practices overlap with major clauses of ISO 9001. A green cell means that the relevant generic practice is adequately covered by the provisions of the associated clauses, while a grey cell indicates that the generic practice is not adequately addressed by any of the clauses in the referenced section of ISO 9001.

Table 4: Detailed Comparison of how Major Clauses of ISO 9001 Overlap with the CMMI-DEV, V1.2 Generic Practices

\begin{tabular}{|l|l|l|l|l|l|}
\hline ISO 9001:2000 Sections & & & & \\
CMMI-DEV, V1.2 & & & & & \\
Generic Practices & & & & & \\
\hline Perform Specific Practices (1.1) & & & & & \\
\hline Establish an Organizational Policy (2.1) & & & & & \\
\hline Plan the Process (2.2) & & & & & \\
\hline Provide Resources (2.3) & & & & & \\
\hline Assian Responsibility (2.4) & & & & & \\
\hline Train People (2.5) & & & & & \\
\hline Manage Confiqurations (2.6) & & & & \\
\hline Identify and Involve Relevant Stakeholders (2.7) & & & & \\
\hline Monitor and Control the Process (2.8) & & & & \\
\hline Obiectively Evaluate Adherence (2.9) & & & & \\
\hline Review Status with Hiaher Level Management (2.10) & & & & \\
\hline Establish a Defined Process (3.1) & & & & \\
\hline Collect Improvement Information (3.2) & & & & \\
\hline Establish Quantitative Obiectives for the Process (4.1) & & & & \\
\hline Stabilize Subprocess Performance (4.2) & & & & \\
\hline Ensure Continuous Process Improvement (5.1) & & & & \\
\hline Correct Root Causes of Problems (5.2) & & & & \\
\hline
\end{tabular}




\subsubsection{Mid-Level Coverage Comparison (CMMI-DEV, V1.2 to ISO 9001)}

The following table shows a mid-level comparison of the content relationships between CMMIDEV, V1.2 and ISO 9001.

A blue cell indicates that the requirements of the ISO 9001 standard would be considered to be satisfied by CMMI-DEV, V1.2 practices (within the relevant process area) without any significant guidance or interpretation.

A green cell indicates that the requirements of the ISO 9001 standard would be satisfied if CMMI-DEV, V1.2 practices (within the relevant process area) were fully interpreted and implemented. For example, clause 4.2.4 discusses the requirement for quality records, but CMMIDEV, V1.2 does not have a process area that is directly equivalent to quality records. However, generic practice 3.2 of the CMMI-DEV, V1.2 model does require data, information, or measurements to be retained throughout the model process. A yellow cell indicates that the requirements of the ISO 9001 standard may be satisfied by CMMI-DEV, V1.2 practices (within the relevant process area) if significant additional interpretation is undertaken. For example, up to maturity level 3 , there is no direct requirement to conduct corrective action in a manner that involves root cause analysis and, therefore, the requirements of the CMMI-DEV, V1.2 model would be satisfied with simple remedial action until Causal Analysis and Resolution is implemented for the organization to achieve maturity level 5. However, should an organization perform some form of root cause analysis on issues - in effect, start to address maturity level 5 needs - then this would satisfy clause 8.5.1 of ISO 9001:2000.

A grey cell indicates that these requirements would be satisfied through implementation of other ISO 9001 clauses and therefore are not addressed separately. For example, clause 8.5.1, which requires continual improvement, is actually demonstrated through a number of other clauses: quality policy (5.3) drives objectives (5.4.1), which are checked through internal audit (8.2.2) and analysis of data (8.4), leading to corrective and preventive action (8.5.2/.3), which is reviewed by management (5.6). Finally, a white cell indicates that there is no significant overlap between the CMMI-DEV, V1.2 model and the ISO 9001 framework in these particular areas. 
Table 5: Mid-Level Comparison of the Content Relationships Between CMMI-DEV, V1.2 and ISO 9001

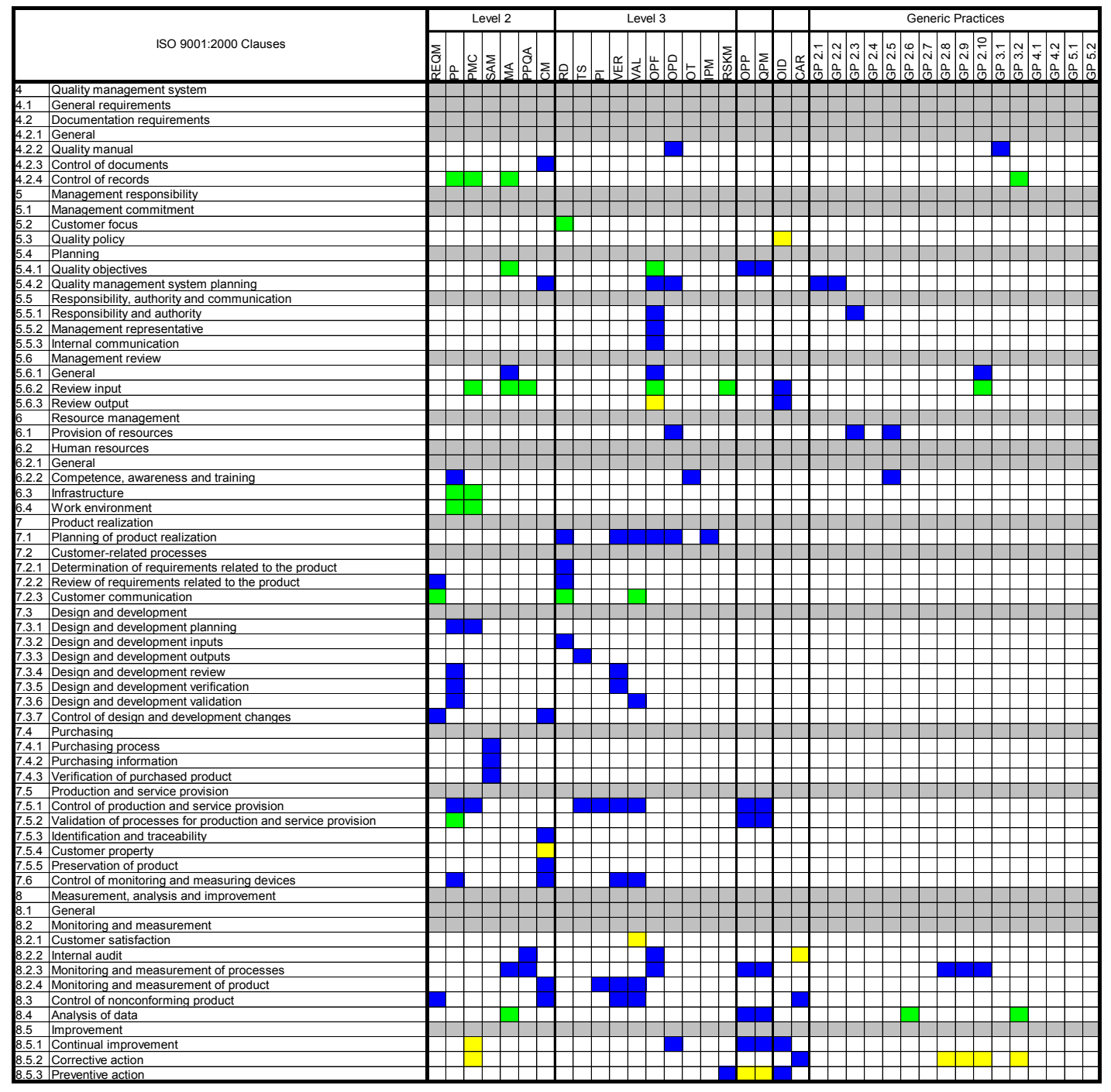




\subsubsection{Mid-Level Coverage Comparison (ISO 9001 to CMMI-DEV, V1.2)}

In general, ISO 9001 does not directly cross-reference with CMMI-DEV, V1.2 process areas, such as Risk Management, Decision Analysis and Resolution, Organizational Process Performance (which is partially met below), Product Integration, or Quantitative Project Management. In general, all other CMMI-DEV, V1.2 process areas are supported to varying extents by ISO 9001 clauses, though no single CMMI-DEV, V1.2 process area is fully supported by ISO 9001 clauses. Likewise, ISO 9001 does not directly cross-reference with the CMMI-DEV, V1.2 generic practices, or even specifically to generic practices 4.1 and 4.2.

For all the other process areas, one could say that ISO 9001 cross-references to the generic practices as ISO 9001 addresses the topics of the generic practices on a one-time (or more) basis for the individual clauses in ISO 9001.

The following table shows a mid-level comparison of the content relationships between ISO 9001 and CMMI-DEV, V1.2 maturity level 2 process areas.

A blue cell indicates that the requirements of the ISO 9001 standard would be considered to be satisfied by CMMI-DEV, V1.2 practices without any additional significant guidance or interpretation.

A green cell indicates that the ISO 9001 clause would be considered to be satisfied if CMMIDEV, V1.2 practices were fully interpreted and implemented. For example, clause 4.2 .4 discusses the requirement for quality records, yet the CMMI-DEV, V1.2 model does not have any directly equivalent process area for quality record requirements. However, generic practice 3.2 of CMMIDEV, V1.2 model does require data, information, and/or measurements to be retained throughout the implementation of the model's practices.

A yellow cell indicates that the requirements of the ISO 9001 standard may be satisfied by CMMI-DEV, V1.2 practices if significant additional interpretation is undertaken. For example, up to maturity level 3 , there is no direct requirement to conduct corrective action in a manner that involves root cause analysis and, therefore, the CMMI-DEV, V1.2 model requirements would be satisfied with simple remedial action. However, should an organization do some form of root cause analysis on issues - in effect, start to address the requirements of maturity level 5 by implementing the process area Causal Analysis and Resolution - then this would satisfy clause 8.5.1 of ISO 9001:2000.

A red cell indicates the determination that nothing in the CMMI-DEV, V1.2 model could cause the ISO 9001 requirement to be satisfied effectively.

A grey cell indicates that these clauses would be satisfied through implementation of other ISO 9001 clauses and therefore are not addressed separately. For example, clause 8.5.1, which requires continual improvement, is actually demonstrated through a number of other clauses: quality policy (5.3) drives objectives (5.4.1), which are checked through internal audit (8.2.2) and analysis of data (8.4), leading to corrective and preventive action $(8.5 .2,8.5 .3)$, which is reviewed by management (5.6). Finally, a white cell indicates that there is no significant overlap between the CMMI-DEV, V1.2 model and the ISO 9001 framework in these particular areas. 
Table 6: Mid-Level Comparison of the Content Relationships Between ISO 9001 and CMMI-DEV, V1.2 Maturity Level 2 Process Areas

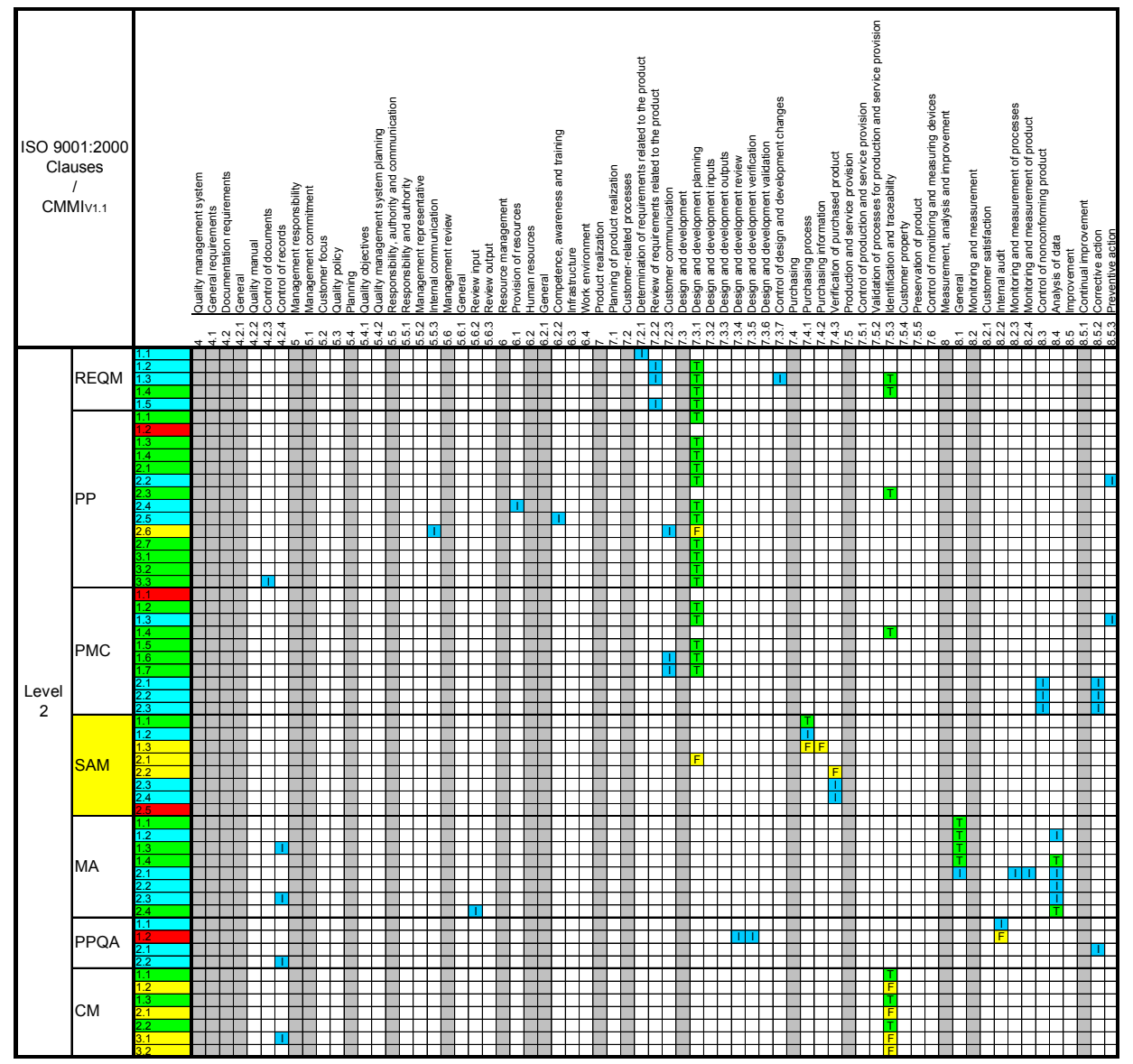


The following table shows a mid-level comparison of the content relationships between ISO 9001 and CMMI-DEV, V1.2 maturity level 3 process areas.

Table 7: Mid-Level Comparison of the Content Relationships Between ISO 9001 and CMMI-DEV, V1.2 Maturity Level 3 Process Areas

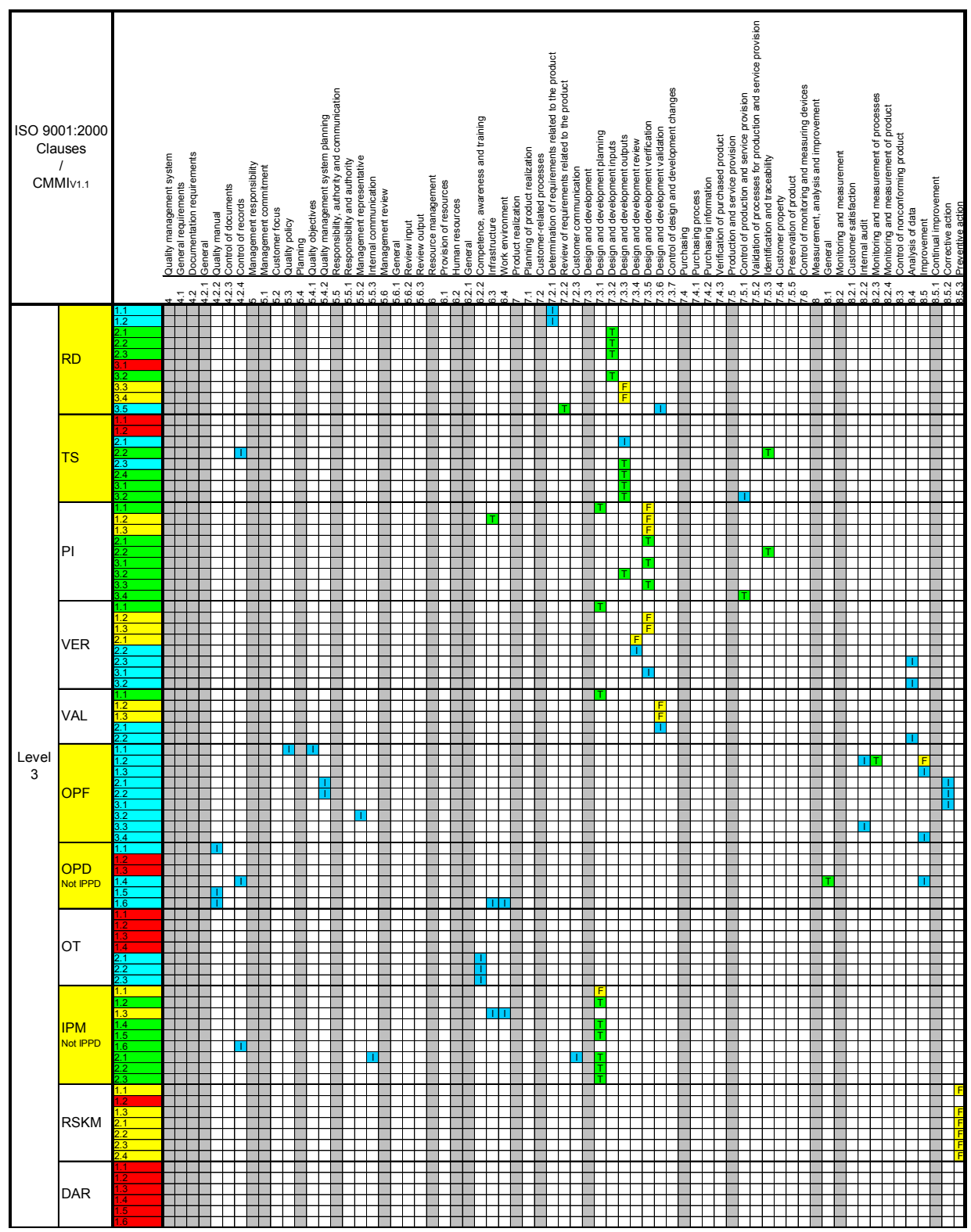


Finally, the following table shows a mid-level comparison of the content relationships between ISO 9001 and the CMMI-DEV, V1.2 maturity level 4 and 5 process areas.

Table 8: $\quad$ Mid-Level Comparison of Content Relationships Between ISO 9001 and CMMI-DEV, V1.2 Maturity Level 4 and 5 Process Areas

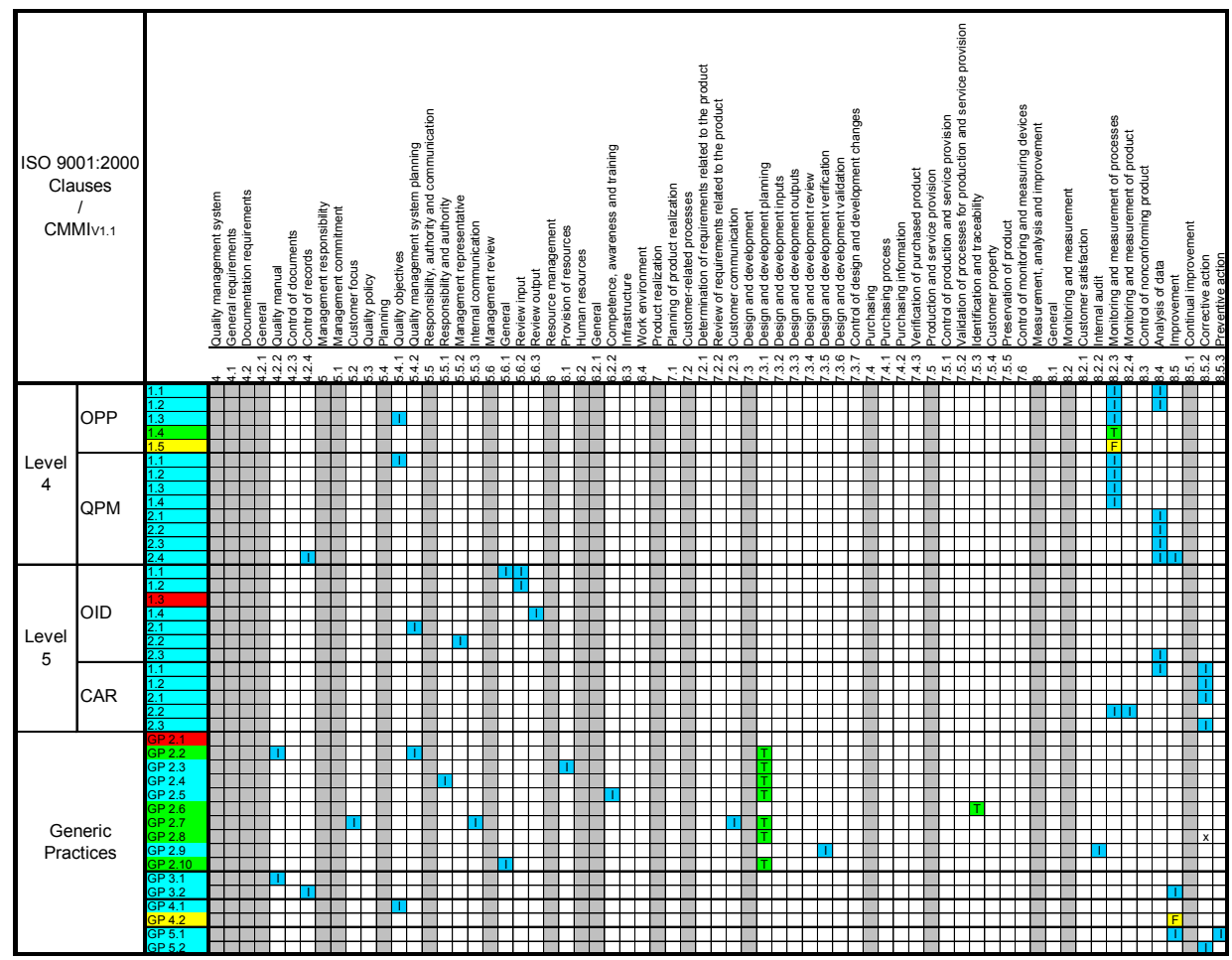




\subsubsection{Treatment of Customer Satisfaction}

One area of difference that a number of previous reports have noted is the way in which the two bodies of knowledge cover customer satisfaction.

In ISO 9001, the treatment is explicit and immediate, while in CMMI-DEV, V1.2, the treatment is indirect and implicit. For example, in ISO 9001, clauses 5.2, 6.1, 8.2.1 and 8.4 all make explicit mention of customer satisfaction. In CMMI-DEV, V1.2, the term customer satisfaction occurs in only three minor informative references. Note that this does not mean customer satisfaction is not an important consideration in the CMMI-DEV, V1.2 model, but rather is more of a reflection of its origins and audience. Customer satisfaction is embedded indirectly in CMMI-DEV, V1.2 in a number of ways, most especially through the inclusion of the definition of the term stakeholder and its pervasive use throughout the model, as well as in the Requirements Development and Validation process areas.

\subsubsection{Treatment of High Maturity}

CMMI-DEV, V1.2 is quite explicit about the required use of quantitative methods at maturity levels 4 and 5, although even at maturity level 2 there are explicit requirements for a measurement capability across the organization.

The ISO 9001 family requires statistics in a very general way, and ISO 9000 and ISO 9004 elaborate on statistics and recommend self-assessments to a model. In a very general way, the requirements of ISO 9000 and ISO 9004 are similar to those of the CMMI-DEV, V1.2 model's maturity level 5 process areas, regarding finding the root causes of problems and making necessary improvements.

The ISO 9000 glossary defines statistical techniques as helping to measure, describe, analyze, interpret, and model variability. ISO/TR 10017 gives guidance on statistical techniques in a quality management system.

ISO 9001 (clause 8.1) requires measurements to “...include determination of applicable methods, including statistical techniques, and the extent of their use.” ISO TR/10017 is referenced; its application has demonstrated the incorporation of high maturity concepts in ISO 9001 standards since 2003.

In ISO 9004, section 8 (Measurement, analysis and improvement), section 8.1.2.j recommends level 4 activity that is consistent with maturity level 4 in CMMI-DEV, V1.2: “...the use of appropriate statistical or other techniques can help in the understanding of both process and measurement variation, and can thereby improve process and product performance by controlling variation..."

ISO 9001 sets the very general basis for high maturity activities with clause 8.4, which requires that the analysis of data shall provide information relating to characteristics and trends of processes and products (generally similar to the CMMI-DEV, V1.2 process area Organizational 
Process Performance) and including opportunities for preventive action (generally similar to the CMMI-DEV, V1.2 process area Quantitative Project Management).

ISO 9004 clause 8.4 builds on the trends above in a way similar to CMMI-DEV, V1.2 maturity level 5 by saying that "...the analysis of data can help to determine the root cause of existing or potential problems (similar to CMMI-DEV, V1.2 process area Causal Analysis and Resolution) and therefore guide decisions about the corrective (similar to CMMI-DEV, V1.2 process areas Causal Analysis and Resolution \& Organizational Innovation and Deployment) and preventive actions needed for improvement (similar to CMMI-DEV, V1.2 process area Organizational Innovation and Deployment)."

Finally, ISO 9004 clause 8.4 states that analysis of data addresses decision making (related to CMMI-DEV, V1.2 process area Decision Analysis and Resolution): "Decisions based on facts require effective and efficient actions such as

- valid analysis methods

- $\quad$ appropriate statistical techniques

- making decisions and taking actions based on results of logical analyses, as balanced with experience and intuition."

\subsection{Appraisal}

This area is probably the source of as much confusion as any other, due to many similarities and a number of subtle but significant differences. The above discussion on terminology differences has already revealed that the results of appraisal in the two approaches hold fundamentally different meanings.

In the world of CMMI-DEV, V1.2, an organization undergoes a formal SCAMPI A appraisal that results in either a maturity level rating, a set of process capability ratings, or both. The appraisal results can then be posted on the SEI's published appraisal results website upon request. The SEI does not operate a certification scheme.

In the ISO 9001 world, an organization undergoes an ISO 9001 audit that, if successful, results in an accredited certificate indicating conformance to ISO 9001 within the scope of the organization and audit, based on the samples of the organization's processes recorded in the audit report.

An accredited certificate is one that has been issued by an accredited certification body, such as Lloyd's Register (LRQA), the British Standards Institution (BSI), or Det Norske Veritas (DNV). These accredited certification bodies are themselves regulated and audited by national accreditation bodies, such as the UKAS in the UK or ANAB in the U.S., against international standards. The accreditation process ensures that the certification bodies apply and undertake the certifications assessments in an appropriate and professional manner. For example, checks are performed to ensure that the certification bodies have appropriate processes in place; that the assessments are conducted by appropriately trained, competent, and certified auditors; and that there is no indication of parallel consultancy being provided by the certification body. To achieve this goal, the recognition of an accredited certificate is generally considered very important. 
The recognition of an accredited certificate is generally considered essential in providing confidence to an organization's customers. Additionally, a certificate awarded by an accredited certification body will carry the logo of the accreditation body.

As mentioned in clause 3, ISO 9001 audit results are recorded in the final audit report for registration, and findings impacting registration are recorded as non-conformances, typically as either minor or major. Minor non-conformances are similar to SCAMPI's Largely Implemented (LI) characterizations, while major non-conformances are similar to SCAMPI's Partially Implemented (PI), Not Implemented (NI), or Not Yet (NY) characterizations.

One interesting difference from the SCAMPI method is that in an ISO 9001 audit, there are no requirements for a minimum number of team members to be present at any particular interview session. In fact, in most cases, team members work independently, apart from regular schedule audit team meetings where data and information is shared between the team. As a consequence, there is a cost differential between the two activities, although proponents of the CMMI-DEV, V1.2 approach would argue that there are substantial benefits associated with the use of teams comprised of practitioners and managers from the organization being examined. There are other differences that translate to the bottom-line costs associated with ISO versus CMMI-DEV, V1.2; an ISO 9001 Lead Auditor needs only one week of formal training, while the CMMI-DEV, V1.2 SCAMPI Lead Appraiser needs three sequential formal training courses and specified related experiences. The result is a dramatic cost difference that is passed on to the organization being appraised. Again, the costs of each approach need to be weighed against the business value that is gained from implementing the approach.

\subsection{Training of Lead Appraisers and Lead Auditors}

SCAMPI Lead Appraisers must satisfy formal educational, continuing education, and experience requirements as a prerequisite to entry into SCAMPI Lead Appraiser training, and they must also be observed successfully completing a SCAMPI A appraisal. Once authorized, they must deliver SCAMPI services under the auspices of an approved SEI Partner organization that assumes responsibility for their professional conduct.

Entry into SCAMPI Lead Appraiser Training requires the following:

- $\quad$ participation as an appraisal team member on at least two SCAMPI A appraisals or on one SCAMPI A appraisal and two SCAMPI B or C appraisals within the prior 24 months

- at least ten years of project management and engineering experience in systems or software engineering

- a minimum of two years of experience managing technical personnel

- an advanced degree in a related technical area or equivalent experience

- $\quad$ successful completion of the three-day Introduction to CMMI course

- $\quad$ successful completion of the five-day Intermediate Concepts of CMMI course [CMMI 2008a]

- $\quad$ successful completion of the five-day SCAMPI Lead Appraiser training 
In order to gain the additional credential as a high maturity SCAMPI Lead Appraiser, appraisers' applications must be accepted by the SEI, and the appraisers must pass a written examination. This credential enables them to lead appraisals for which the target maturity level is 4 or 5 .

ISO 9001 Lead Auditor candidates must also undergo appropriate and recognized certified training in order to conduct audits that would result in an accredited certificate for an organization. This training typically consists of a one-week Lead Auditor course, which culminates in an open book examination. The training, which will have been accredited by a national accrediting agency, consists of lecture-based material, exercises, role-playing practice audits, and an examination. After completing the Lead Auditor exam successfully, the candidate becomes a Trainee Auditor.

To advance, the candidate must complete four audits of a Quality System covering 20 audit days of effort under the guidance of a Lead Auditor. Following completion, the Certification Body Management will review this performance; if the review is favorable, the Trainee Auditor will be upgraded to an Auditor.

After the Auditor completes three audits in a lead role covering 15 audit days of effort, his or her performance is reviewed; if performance is deemed acceptable, the Auditor is upgraded to a Lead Auditor.

The Auditors are also qualified in certain EAC code sectors (industry sectors) based on their education and experience in that sector. The performance of Auditors and Lead Auditors is periodically monitored by the Certification Body and the records of the same are maintained. The Accreditation Body audits these records during the yearly surveillance audit.

\subsection{Supporting infrastructure}

Both approaches have significant support networks in place. The main differences are that the SEI does not have a true certification scheme currently established and the appraisal bestows one of five levels of maturity, while the ISO 9001 does have a certification scheme with a single outcome-pass or fail.

Additionally, the CMMI initiative parallels ISO 9001, in the sense that the CMMI initiative is partially DoD- and industry-sponsor-driven, while ISO 9001 is driven by the associated international standardization infrastructure.

\subsection{Adoption}

This section focuses on the current degree of adoption of the two approaches by examining the number of organizations that have achieved formal levels of achievement, as well as miscellaneous secondary indicators of adoption. The intent is not to suggest that one or the other approaches is "better" or "worse" than the other based on the comparison of the degrees of adoption, but rather to simply provide some factual information on the extent of the adoption of the two approaches.

As ISO 9001 is a generic standard for all organizations, it has a much larger deployment area than the CMMI initiative. Many product development organizations are finding advantages for using 
ISO 9001 and CMMI-DEV, V1.2 in tandem. ISO 9001 provides confidence to the casual customer and CMMI-DEV, V1.2 provides details for process improvements. 


\subsection{Comparative Summary}

Table 9: $\quad$ Comparison of Attributes of ISO 9001 and CMMI-DEV, V1.2

\begin{tabular}{|c|c|c|}
\hline Attribute & ISO 9001 & $\begin{array}{l}\text { Capability Maturity Model-Integrated for } \\
\text { Development (CMMI-DEV) }\end{array}$ \\
\hline Applicability & All organizations & Organizations that develop products \\
\hline $\begin{array}{l}\text { Source of } \\
\text { Requirements }\end{array}$ & $\begin{array}{l}\text { ISO } 9001: 2000, \text { ISO } \\
9000: 2000\end{array}$ & CMMI-DEV, V1.2 \\
\hline Doc. Size & 24,36 pages & 600 pages \\
\hline Doc. Cost & $\$ 52+\$ 52$ & Free download \\
\hline Cognizant Body & ISO TC 176 & $\begin{array}{l}\text { The Software Engineering Institute (SEI) } \\
\text { (U.S. DoD-sponsored) }\end{array}$ \\
\hline Organization & $\operatorname{SC} 1,2,3$ & $\begin{array}{l}\text { Revisions, Training, Auditors, Best Practices } \\
\text { Conf, Trials }\end{array}$ \\
\hline Advising Bodies & National (e.g., U.S. TAG) & $\begin{array}{l}\text { SEI Partners, CMMI Steering Group, SEI } \\
\text { Partner Advisory Board }\end{array}$ \\
\hline Accreditation Bodies & $\begin{array}{l}\text { Depends on the country of } \\
\text { interest }\end{array}$ & $\begin{array}{l}\text { The SEI Is probably the closest thing in the } \\
\text { CMMI world. }\end{array}$ \\
\hline Support & $\begin{array}{l}\text { Depends on the country of } \\
\text { interest }\end{array}$ & $\begin{array}{l}\text { The Software Engineering Institute (SEI) } \\
\text { (U.S. DoD-sponsored) }\end{array}$ \\
\hline Conformance & Pass/Fail & $\begin{array}{l}\text { Organization can receive a capability level } \\
\text { and/or a maturity level. }\end{array}$ \\
\hline $\begin{array}{l}\text { Conformance } \\
\text { Document }\end{array}$ & $\begin{array}{l}\text { ISO } 19011, \\
\text { Guide } 62\end{array}$ & $\begin{array}{l}\text { Standard CMMI Appraisal Method for } \\
\text { Process Improvement (SCAMPI) for class A, } \\
\text { B, or C }\end{array}$ \\
\hline Certified Bodies (CB) & 100 's & One: The SEI \\
\hline Certified Training Org. & 20 in U.S. & The SEI and other SEI Partners \\
\hline Qualified Auditors & Thousands & 100+ Lead Appraisers \\
\hline Conformance & 780K Certifications & $3000+$ Appraisals \\
\hline Major Issues & Certification Creditability & Training and appraisal costs \\
\hline Liaisons & Sectors & ISO/IEC JTC1 SC7, IEEE, INCOSE, NDIA \\
\hline Guidance Books & Many & Many \\
\hline
\end{tabular}




\section{Appendix A: Individual and Organizational Contributors}

\section{Sponsors}

The following organizations contributed as sponsors of this initial report. Sponsorship took the form of direct financial contributions, program management, or by sanctioning members to contribute to the development of the report.

- Lockheed Martin Integrated Systems and Solutions

- Software Engineering Institute

- Z1 Quality Management committee of the American Society for Quality

\section{Authors}

These individuals developed the report and contributed new or existing material:

- David H. Kitson (Software Engineering Institute Visiting Scientist-project manager and report editor, High Maturity SCAMPI Lead Appraiser, SCAMPI Lead Appraiser Observer, Introduction to CMMI V1.2 Instructor, Intermediate CMMI V1.2 Instructor, former working group convener for ISO/IEC JTC1 WG22)

- $\quad$ Robert Vickroy (ABS Quality Evaluations, Inc., SCAMPI Lead Appraiser, Introduction to CMMI V1.2 Instructor, ASQ-CQA, ICCP-CDP, EDPA-ISACA and ISC2 security auditor, NQA-1 auditor)

- John Walz (The Sutton Group, Z1 Quality Management committee representative)

- David Wynn (Computer Sciences Corporation, SCAMPI Lead Appraiser, Registered ISO 9001:2000/Tick IT Lead Auditor)

I wanted to give special mention to the contributions made by my fellow authors, and to again thank them for their continued support and patience. Bob Vickroy was especially strong in his expertise in both bodies of knowledge and made more valuable suggestions than I could absorb. John Walz did an exemplary job of serving as liaison with the Z1 committee. Dave Wynn gave freely of his extensive work in mapping the two bodies of knowledge and was a great source of insight. Thanks also go to the Tick IT International Journal for giving permission for the inclusion of some of Dave's mapping work first published there [Wynn 2005, Wynn 2006, Wynn 2007].

\section{Reviewers}

These individuals reviewed and commented on the draft report prior to publication. Note that some of the reviewers were invited to be authors, but for varying reasons were unable to commit to that role at the time a commitment was needed: 
- $\quad$ L.L. "Buddy" Cressionnie (Lockheed Martin Aeronautics, Quality \& Mission Success Processes Senior Manager, RABQSA Aerospace Industry Experience Auditor, IRCA QMS and EMS Lead Auditor, U.S. Technical Advisory Group (TAG) to ISO/TC 176 Voting Member, Z1 Committee member)

- Scott Duncan (ASQ Software Division, TSP Coach)

- Margaret Glover (Software Engineering Institute, High Maturity SCAMPI Lead Appraiser, SCAMPI Lead Appraiser Observer, Introduction to CMMI V1.2 Instructor, Intermediate CMMI V1.2 Instructor)

- Venkat Gopalan (Cyber Solutions, Inc., SCAMPI Lead Appraiser, Introduction to CMMI V1.2 Instructor)

- $\quad$ Eugene Kirsch (Booz $\mid$ Allen $\mid$ Hamilton, Z1 Committee member)

- Mike Konrad (Software Engineering Institute, Introduction to CMMI V1.2 Instructor, CMMI IT Instructor, Intermediate CMMI V1.2 Instructor)

- $\quad$ Larry McCarthy (Motorola Software Group, High Maturity SCAMPI Lead Appraiser)

- $\quad$ Norm Moreau (Theseus Professional Services, LLC, ISO lead auditor)

- Boris Mutafelija (Systems and Software Consortium, Inc., SCAMPI Lead Appraiser, Introduction to CMMI V1.2 Instructor)

- Geetha Partha (Quality Point Integrating Systems LLC, SCAMPI Lead Appraiser, Introduction to CMMI V1.2 Instructor)

- $\quad$ Ramachandran Partha (Quality Point Integrating Systems LLC, SCAMPI Lead Appraiser)

- Terry Rout (Software Quality Institute, SCAMPI Lead Appraiser, Introduction to CMMI V1.2 Instructor, CMMI IT Instructor, Intermediate CMMI V1.2 Instructor)

- $\quad$ Pedro Sousa (Cobra Automotive Technologies S.p.A.)

- Angela Tuffley (Software Quality Institute, SCAMPI Lead Appraiser, Introduction to CMMI V1.2 Instructor, CMMI IT Instructor, Intermediate CMMI V1.2 Instructor)

- Joan Weszka (Lockheed Martin Systems \& Software Resource Center, Corporate Engineering and Technology, Introduction to CMMI V1.2 Instructor) 


\section{Appendix B: List of Acronyms}

\section{ISO Acronyms}

BSI-British Standards Institute

ISO - International Organization for Standardization

$\mathrm{SC}$-Sub-committee

TC_-Technical Committee

ISO 9001 Body of Knowledge Acronyms

AB - accreditation body

$\mathrm{CB}$ - certification body

\section{CMMI Body of Knowledge Acronyms}

CMM - Capability Maturity Model

CMMI - Capability Maturity Model Integration

CMMI-ACQ - CMMI for Acquisition

CMMI-DEV-CMMI for Development

CMMI-SVC - CMMI for Services

CMMI SG-CMMI Steering Group

DOD—Department of Defense

NDIA-National Defense Industrial Association

SEI—Software Engineering Institute

PA-process area

$\mathrm{SP}$ - specific practice

GP-generic practice

SG-specific goal

GG-generic goal

SCAMPI-Standard CMMI Appraisal Method for Process Improvement

ARC-Appraisal Requirements for CMMI

EPG-Engineering Process Group

SEPG-Software Engineering Process Group 
42 | CMU/SEI-2009-SR-005 


\section{Appendix C: Terminology Differences}

Table 10: A Comparison of Terminology Definitions for ISO 9000 and CMMI-DEV, V1.2

\section{ISO 9000}

3.9.1 Audit-"systematic, independent and documented process for obtaining audit evidence and evaluating it objectively to determine the extent to which audit criteria are fulfilled"

\subsubsection{Capability-"ability of an} organization, system or process to realize a product that will fulfill the requirements for that product"

2.9 Continual improvement--"The aim of continual improvement of a quality management system is to increase the probability of enhancing the satisfaction of customers and other interested parties."

\subsubsection{Corrective action-"action to} eliminate a detected nonconformity"

3.3.5 Customer-“organization or person that receives a product"
CMMI for Development, V1.2

Audit-“in CMMI process improvement work, an objective examination of a work product or set of work products against specific criteria (e.g., requirements)." Clearly, this definition refers to the use of the term audit as an activity taking place within the product developing organization.

Capability level_-"achievement of process improvement within an individual process area. A capability level is defined by the appropriate specific and generic practices for a process area"

Process improvement-"a program of activities designed to improve the performance and maturity of the organization's processes and the results of such a program"

Corrective action-“acts or deeds used to remedy a situation, remove an error, or adjust a condition"

Customer-"the party (individual, project, or organization) responsible for accepting the product or for authorizing payment. The customer is external to the project, but not necessarily external to the organization. The customer may be a higher level project. Customers are a subset of stakeholders."

3.6.3 Defect-“non-fulfillment of a requirement related to an intended or specified use"

\subsubsection{Design and development-"set of} processes that transforms requirements into specified characteristics or into the specification of a product, process, or system"

\section{Defect Density-"number of defects per unit of product} size (e.g., problem reports per thousand lines of code)"

Development-“'In the CMMI Product Suite, not only development activities but also maintenance activities may be included. Projects that benefit from the best practices of CMMI can focus on development, maintenance, or both"

3.7.1 Document-“information and its supporting medium"

Document-"a collection of data, regardless of the medium in which it is recorded, that generally has permanence and can be read by humans or machines. So, documents include both paper and electronic documents."

3.2.6 Management- "coordinated activities to direct and control an organization"
Manager-“in the CMMI Product Suite, a person who provides technical and administrative direction and control to those performing tasks or activities within a specified area of responsibility. The traditional functions of a manager include planning, organizing, directing, and controlling work within an area of responsibility." 


\begin{tabular}{|c|c|}
\hline ISO 9000 & CMMI for Development, V1.2 \\
\hline $\begin{array}{l}\text { 3.10.1 Measurement management } \\
\text { system-"set of interrelated and interacting } \\
\text { elements necessary to achieve metrological } \\
\text { confirmation and continual control of } \\
\text { measurement processes" }\end{array}$ & $\begin{array}{l}\text { Organization's measurement repository-"a repository } \\
\text { used to collect and make available measurement data on } \\
\text { processes and work products, particularly as they relate to } \\
\text { the organization's set of standard processes. This } \\
\text { repository contains or references actual measurement } \\
\text { data and related information needed to understand and } \\
\text { analyze the measurement data." }\end{array}$ \\
\hline $\begin{array}{l}\text { 3.8.1 Objective evidence-“data } \\
\text { supporting the existence or verity of } \\
\text { something" }\end{array}$ & $\begin{array}{l}\text { Objective evidence-“as used in CMMI appraisal } \\
\text { materials, documents or interview results used as } \\
\text { indicators of the implementation or institutionalization of } \\
\text { model practices. Sources of objective evidence can } \\
\text { include instruments, presentations, documents, and } \\
\text { interviews." }\end{array}$ \\
\hline $\begin{array}{l}\text { 3.3.1 Organization-“"group of people and } \\
\text { facilities with an arrangement of } \\
\text { responsibilities, authorities, and } \\
\text { relationships" }\end{array}$ & $\begin{array}{l}\text { Organization-“typically an administrative structure in } \\
\text { which people collectively manage one or more projects as } \\
\text { a whole, and whose projects share a senior manager and } \\
\text { operate under the same policies. However, the word } \\
\text { organization as used throughout CMMI models can apply } \\
\text { to one person who performs a function in a small } \\
\text { organization that might be performed by a group of people } \\
\text { in a large organization." }\end{array}$ \\
\hline $\begin{array}{l}\text { 3.4.1 Process-"set of interrelated or } \\
\text { interacting activities that transforms inputs } \\
\text { into outputs" }\end{array}$ & $\begin{array}{l}\text { Process-“activities that can be recognized as } \\
\text { implementations of practices in a CMMI model. These } \\
\text { activities can be mapped to one or more practices in } \\
\text { CMMI process areas to allow a model to be useful for } \\
\text { process improvement and process appraisal." }\end{array}$ \\
\hline 3.4.2 Product-“result of a process" & $\begin{array}{l}\text { Product-“"The word "product" is used throughout the } \\
\text { CMMI Product Suite to mean any tangible output or } \\
\text { service that is a result of a process and that is intended for } \\
\text { delivery to a customer or end user. A product is a work } \\
\text { product that is delivered to the customer." }\end{array}$ \\
\hline $\begin{array}{l}\text { 3.4.3 Project- "unique process, consisting } \\
\text { of a set of coordinated and controlled } \\
\text { activities with start and finish dates, } \\
\text { undertaken to achieve an objective } \\
\text { conforming to specific requirements, } \\
\text { including the constraints of time, cost and } \\
\text { resources" }\end{array}$ & $\begin{array}{l}\text { Project-“a managed set of interrelated resources that } \\
\text { delivers one or more products to a customer or end user. } \\
\text { This set of resources has a definite beginning and end } \\
\text { and typically operates according to a plan. Such a plan is } \\
\text { frequently documented and specifies the product to be } \\
\text { delivered or implemented, the resources and funds to be } \\
\text { used, the work to be done, and a schedule for doing the } \\
\text { work. A project can be composed of projects." }\end{array}$ \\
\hline $\begin{array}{l}\text { 3.1.1 Quality_-"degree to which a set of } \\
\text { inherent characteristics fulfils requirements" }\end{array}$ & $\begin{array}{l}\text { Quality--the ability of a set of inherent characteristics of } \\
\text { a product, product component, or process to fulfill } \\
\text { requirements of customers" }\end{array}$ \\
\hline $\begin{array}{l}\text { 3.2.11 Quality assurance-_part of quality } \\
\text { management focused on providing } \\
\text { confidence that quality requirements will be } \\
\text { fulfilled" }\end{array}$ & $\begin{array}{l}\text { Quality Assurance_-a planned and systematic means } \\
\text { for assuring management that the defined standards, } \\
\text { practices, procedures, and methods of the process are } \\
\text { applied" }\end{array}$ \\
\hline
\end{tabular}


ISO 9000

3.2.5 Quality objective-_"something

sought, or aimed for, related to quality"
CMMI for Development, V1.2

Quality and Process-Performance Objectives"objectives and requirements for product quality, service quality, and process performance. Process performance objectives include product quality; however, to emphasize the importance of product quality, the phrase quality and process-performance objectives is used in the CMMI Product Suite rather than just process performance objectives.

\subsubsection{Quality Management System} (QMS) - "management system to direct and control an organization with regard to quality"

3.2.4 Quality policy-“overall intentions and direction of an organization related to quality as formally expressed by top management"

3.1.2 Requirement-“need or expectation that is stated, generally implied, or obligatory" that provides a product"

3.8.3 Test- - "determination of one or more characteristics according to a procedure"

3.2.7 Top management-“"person or group of people who directs and controls an organization at the highest level"

3.5.4 Traceability - "ability to trace the history, application or location of that which is under consideration"

This term has no direct analogue in CMMI-DEV, V1.2.
Organizational policy-“A guiding principle typically established by senior management that is adopted by an organization to influence and determine decisions."
Requirement-“(1) a condition or capability needed by a user to solve a problem or achieve an objective. (2) a condition or capability that must be met or possessed by a product or product component to satisfy a contract, standard, specification, or other formally imposed documents. (3) a documented representation of a condition or capability as in (1) or (2)"

Supplier-“(1) an entity delivering products or performing services being acquired. (2) an individual, partnership, company, corporation, association, or other service having an agreement (contract) with an acquirer for the design, development, manufacture, maintenance, modification, or supply of items under the terms of an agreement (contract)."

Test procedure-“detailed instructions for the setup, execution, and evaluation of results for a given test"

Senior Manager-“in the CMMI Product Suite, a management role at a high enough level in an organization that the primary focus of the person filling the role is the long-term vitality of the organization rather than short-term project and contractual concerns and pressures. A senior manager has authority to direct the allocation or reallocation of resources in support of organizational process improvement effectiveness. (See also 'higher level management.') A senior manager can be any manager who satisfies this description, including the head of the organization. Synonyms for senior manager include executive and top-level manager. However, to ensure consistency and usability, these synonyms are not used in CMMI models."

Traceability-"a discernible association among two or more logical entities such as requirements, system elements, verifications, or tasks" 


\begin{tabular}{l|l}
\hline ISO 9000 & CMMI for Development, V1.2 \\
\hline $\begin{array}{l}\text { 3.8.4 Verification-“confirmation, through } \\
\text { the provision of objective evidence, that } \\
\text { specified requirements have been fulfilled" }\end{array}$ & $\begin{array}{l}\text { Verification-“"confirmation that work products properly } \\
\text { reflect the requirements specified for them. In other words, } \\
\text { verification ensures that "you built it right." }\end{array}$ \\
\hline $\begin{array}{l}\text { 3.8.5 Validation-“confirmation, through } \\
\text { the provision of objective evidence, that the } \\
\text { requirements for a specific intended use or } \\
\text { application have been fulfilled" }\end{array}$ & $\begin{array}{l}\text { Validation-"confirmation that the product, as provided } \\
\text { (or as it will be provided), will fulfill its intended use. In } \\
\text { other words, validation ensures that "you built the right } \\
\text { thing." }\end{array}$ \\
\hline
\end{tabular}




\section{Appendix D: Body of Knowledge Resources}

The purpose of the material in this appendix is to identify primary sources of information for parties wishing to maintain currency in the ISO 9000 and CMMI bodies of knowledge. Resources identified are focused on primary sources of current authoritative information, publications and conferences.

\section{ISO 9000 Body of Knowledge}

ISO Management Systems - a bi-monthly publication from the ISO Central Secretariat Quality Digest - a (free) monthly publication for quality assurance and control professionals, from top-level managers to those on the shop floor.

Quality Systems Update - a monthly industry journal focusing on ISO 9000-related matters.

TC176 web site (http://www.tc176.org/default.asp) - this is the "home" for the technical committee within ISO that is responsible for the 9000 family of standards.

ISO 9001 Auditing Practices Group

(http://isotc.iso.org/livelink/livelink/fetch/2000/2122/138402/138403/3541460/customview.html?f unc $=11 \&$ objId $=3541460 \&$ objAction=browse \&sort=name) - this is the "home" for the auditing practices group

Tick IT International - The quarterly journal of the Tick IT software quality certification scheme ISSN 1354-5884; frequently contains articles of interest to both the ISO 9000 as well as the CMMI community. http://www.tickit.org/international.htm

\section{CMMI Body of Knowledge}

SEI website (http://www.sei.cmu.edu) - this is the primary source for information and status for the CMMI Product Suite.

CMMI User's Group conference - an annual conference focusing on CMMI-related matters sponsored by the NDIA in conjunction with the SEI. Annual attendance is 300-500.

SEPG Conferences - annual conferences focusing on engineering process groups and their success; annual attendance at SEPG North America is from 1000-1500.

Yahoo CMMI discussion group - an informal and unofficial discussion group that CMMI practitioners often use to help sort out complex CMMI-related matters.

SCAMPI MDD — resource for SCAMPI Lead Appraisers to provide requirements, activities, and practices associated with each of the processes that comprise the SCAMPI method. 
Training courses - provided by the SEI and by SEI Partners. A full list of courses is available on the SEI website. 


\section{References}

\section{[Bernard 2005]}

Bernard, Tom; Gallagher, Brian; Bate, Roger; \& Wilson, Hal. CMMI Acquisition

Module (CMMI-AM), Version 1.1 (CMU/SEI-2005-TR-011, ADA441245). Software

Engineering Institute, Carnegie Mellon University, 2005

http://www.sei.cmu.edu/publications/documents/05.reports/05tr011.html

[CMMI 2008a]

Software Engineering Institute, Carnegie Mellon University. Intermediate Concepts of CMMI Version 1.2, 2008. http://www.sei.cmu.edu/products/courses/a02b.html

\section{[CMMI 2008b]}

Software Engineering Institute, Carnegie Mellon University. Understanding CMMI High Maturity Practices with Statistics Course, 2008.

http://www.sei.cmu.edu/products/courses/high-maturity-statistics.html

\section{[CMMI 2008c]}

Software Engineering Institute, Carnegie Mellon University. CMMI Version 1.2 Instructor Training, 2008. http://www.sei.cmu.edu/products/courses/p37b.html

[CMMI 2008d]

Software Engineering Institute, Carnegie Mellon University. Introduction to CMMI Version 1.2, 2008. http://www.sei.cmu.edu/products/courses/p44b.html

\section{[CMMI 2008e]}

Software Engineering Institute, Carnegie Mellon University. Software Engineering Institute. CMMI Steward, 2008.

http://www.sei.cmu.edu/cmmi/background/steward.html

[CMMI Product Team 2006]

CMMI Product Team. CMMI for Development, Version 1.2 (CMU/SEI-2006-TR-008, ADA455858). Software Engineering Institute, Carnegie Mellon University, 2006. http://www.sei.cmu.edu/publications/documents/06.reports/06tr008.html

\section{[CMMI Product Team 2007]}

CMMI Product Team. CMMI for Acquisition, Version 1.2 (CMU/SEI-2007-TR-017).

Software Engineering Institute, Carnegie Mellon University, 2007.

http://www.sei.cmu.edu/publications/documents/07.reports/07tr017.html

\section{[CMMI Steering Group 2008]}

Software Engineering Institute, Carnegie Mellon University. CMMI Steering Group, 2008. http://www.sei.cmu.edu/cmmi/background/steering-group.html 


\section{[Dodson 2006]}

Dodson, Kathryn M.; Hofmann, Hubert F.; Ramani, Gowri S; \& Yedlin, Deborah K. Adapting CMMI for Acquisition Organizations: A Preliminary Report (CMU/SEI-2006SR-005, ADA453524). Software Engineering Institute, Carnegie Mellon University, 2006. http://www.sei.cmu.edu/publications/documents/06.reports/06sr005.html

\section{[Hayes 2005]}

Hayes, Will; Miluk, Gene; Ming, Lisa; Glover, Margaret; \& members of the SCAMPI B and C Project. Handbook for Conducting Standard CMMI Appraisal Method for Process Improvement (SCAMPI) B and C Appraisals, Version 1.1 (CMU/SEI-2005HB-005, ADA443682). Software Engineering Institute, Carnegie Mellon University, 2005. http://www.sei.cmu.edu/publications/documents/05.reports/05hb005.html

\section{[Hoyle 2002]}

Hoyle, David \& Thompson, John. ISO 9000:2000: Auditing Using the Process Approach. Amsterdam; New York: Butterworth-Heinemann, 2002 (ISBN:

0750675977). http://www.loc.gov/catdir/description/els031/2002071150.html

\section{[Hoyle 2003]}

David Hoyle. ISO 9000: 2000: An A-Z Guide. Oxford; Boston, MA: ButterworthHeinemann, 2003 (ISBN: 0750658444).

http://www.loc.gov/catdir/toc/els031/2002038518.html

\section{[Humphrey 1987]}

Watts S. Humphrey. Characterizing the Software Process: A Maturity Framework (CMU/SEI-87-TR-011). Software Engineering Institute, Carnegie Mellon University, 1987. http://www.sei.cmu.edu/publications/documents/87.reports/87.tr.011.html

\section{[ISO 2000a]}

International Organization for Standardization. ISO 9001:2000, Quality Management Systems - Requirements, 3rd edition.

http://www.iso.org/iso/catalogue_detail?csnumber=21823

\section{[ISO 2000b]}

International Organization for Standardization. ISO 9004:2000, Quality Management Systems - Guidelines for Performance Improvements, 2nd edition.

http://www.iso.org/iso/catalogue_detail?csnumber=28692

[ISO 2003]

International Organization for Standardization. ISO/TR 10017:2003, Guidance on Statistical Techniques for ISO 9001:2000, 2nd edition.

http://www.iso.org/iso/catalogue_detail?csnumber=36674

\section{[ISO 2004]}

International Organization for Standardization. ISO 9001 Auditing Practices Group Guidance, The Need for a Two-stage Approach to Auditing.

http://isotc.iso.org/livelink/livelink/3554893/APG-

2stage. doc $?$ func $=$ doc. Fetch\&nodeid $=3554893$ 
[ISO 2005]

International Organization for Standardization. ISO 9000:2005, Quality Management Systems - Fundamentals and Vocabulary, 3rd edition.

http://www.iso.org/iso/iso_catalogue/catalogue_tc/catalogue_detail.htm?csnumber=4 2180

[ISO 2006a]

International Organization for Standardization. ISO/TR 10014:2006, Quality

Management_Guidelines for Realizing Financial and Economic Benefits, 1st edition. http://www.iso.org/iso/iso_catalogue/catalogue_tc/catalogue_detail.htm?csnumber=3 7263

[ISO 2006b]

International Organization for Standardization. ISO/TC 176 N881, Sector Specific Documentation List.

http://www.kab.or.kr/Common/Common_DownLoadFile.asp?FileCodeValue=1RTWo OafxqN1

\section{[ISO 2006c]}

International Organization for Standardization. ISO/IEC 17021:2006, Conformity Assessment-Requirements for Bodies Providing Audit and Certification of Management Systems, 1st edition.

http://www.iso.org/iso/iso_catalogue/catalogue_tc/catalogue_detail.htm?csnumber=2 9343

\section{[ISO 2007a]}

International Organization for Standardization. ISO/IEC 17011:2004, Conformity Assessment-General Requirements for Accreditation Bodies Accrediting Conformity Assessment Bodies, 1st edition.

http://www.iso.org/iso/iso_catalogue/catalogue_tc/catalogue_detail.htm?csnumber=2 9332

\section{[ISO 2007b]}

International Organization for Standardization. ISO 19011:2002, Guidelines for Quality and/or Environmental Management Systems Auditing, 1st edition. http://www.iso.org/iso/iso_catalogue/catalogue_tc/catalogue_detail.htm?csnumber=3 1169

\section{[ISO 2008]}

International Organization for Standardization. ISO/IEC 17024:2003, Conformity Assessment - General Requirements for Bodies Operating Certification of Persons, 1st edition.

http://www.iso.org/iso/iso_catalogue/catalogue_tc/catalogue_detail.htm?csnumber=2 9346

[ISO/IEC 2003]

ISO/IEC 15504:2003 Information Technology_Process Assessment-Part 2:

Performing an Assessment.

http://www.iso.org/iso/iso_catalogue/catalogue_tc/catalogue_detail.htm?csnumber=3 7458 
[ISO/IEC 2004]

International Organization for Standardization. ISO/IEC 90003:2004, Software and System Engineering — Guidelines for the Application of ISO 9001:20000 to

Computer Software. http://www.iso.org/iso/catalogue_detail?csnumber=35867

[ISO/IEC 2008a]

International Organization for Standardization. ISO/IEC Directives, Part 1 -

Procedures for the Technical Work, 6th edition.

http://isotc.iso.org/livelink/livelink.exe/fetch/2000/2122/3146825/4229629/4230450/4

230455/ISO_IEC_Directives_Part_1_Procedures_for_the_technical_work__ 2008

6th_ed._PDF_format_?nodeid $=4230504 \&$ vernum $=0$

\section{[ISO/IEC 2008b]}

International Organization for Standardization. ISO/IEC Directives, Part 2 - Rules for the Structure and Drafting of International Standards, 6th edition.

http://isotc.iso.org/livelink/livelink/fetch/2000/2122/3146825/4229629/4230450/42304 56/ISO_IEC_Directives_Part_2_Rules_for_the_structure_and_drafting_of_Internat ional_Standards_2004_5th_edition__pdf_format_pdf?nodeid=4230517\& $\overline{\text { evernum }}$ $=0$

\section{[Johnson 2007]}

Wayne E. Johnson. "AS9100: On Course and Gaining Altitude." Quality Digest 27, 2 February 2007, 43-48.

\section{[Mutafelija 2003a]}

Boris Mutafelija \& Harvey Stromberg. Systematic Process Improvement Using ISO 9001:2000 and CMMI. Boston: Artech House, 2003. (ISBN: 1580534872).

\section{[Mutafelija 2003b]}

Software Engineering Institute. Mappings of ISO 9001:2000 and CMMI Version 1.1. http://www.sei.cmu.edu/cmmi/adoption/iso-mapping.html

\section{[NDIA 2008]}

NDIA. "National Defense Industrial Association." http://www.ndia.org/

\section{[OUSD 2008]}

OUSD. "Office of the Under Secretary of Defense for Acquisition, Technology, and Logistics (OUSD AT\&L)." http://www.acq.osd.mil

\section{[Paradis 2002]}

Paradis, Gerald W., \& Trubiano, John R. Demystifying ISO 9001:2000. Upper Saddle River, NJ: Prentice Hall, 2002 (ISBN: 0130620467).

\section{[Paulk 1993a]}

Paulk, Mark C.; Curtis, Bill; Chrissis, Mary Beth; \& Weber, Christine. Capability

Maturity Model for Software (Version 1.1) (CMU/SEI-93-TR-024, ADA263403).

Software Engineering Institute, Carnegie Mellon University. 1993.

http://www.sei.cmu.edu/publications/documents/93.reports/93.tr.024.html 


\section{[Paulk 1993b]}

Paulk, Mark C.; Weber, Christine; Garcia, Suzanne; Chrissis, Mary Beth; \& Bush, Marilyn. Key Practices of the Capability Maturity Model Version 1.1 (CMU/SEI-93TR-025, ADA263432). Software Engineering Institute, Carnegie Mellon University, 1993. http://www.sei.cmu.edu/publications/documents/93.reports/93.tr.025.html

\section{[Paulk 1994]}

Paulk, Mark C. A Comparison of ISO 9001 and the Capability Maturity Model for Software (CMU/SEI-94-TR-012, ADA290697). Software Engineering Institute, Carnegie Mellon University, 1994.

http://www.sei.cmu.edu/publications/documents/94.reports/94.tr.012.html

\section{[Richter 2008]}

Richter, Karen. CMMI for Acquisition (CMMI-ACQ) Primer, Version 1.2 (CMU/SEI-2008TR-010, ADA482310). Carnegie Mellon University, Software Engineering Institute, 2008. http://www.sei.cmu.edu/publications/documents/08.reports/08tr010.html

\section{[Roberts 2007]}

Roberts, Michael C. "Aerospace Standards Embrace an Unlimited Future." Quality Digest 27, 2 February 2007, 49-53.

\section{[Robitaille 2006]}

Robitaille, Denise, \& West, Jack. "ISO 9000: Then and Now - How Far Have We Come?" Quality Digest 26, 11, 26-33.

\section{[SCAMPI Upgrade Team 2006a]}

SCAMPI Upgrade Team. Appraisal Requirements for CMMI, Version 1.2 (ARC, V1.2) (CMU/SEI-2006-TR-011, ADA465612). Software Engineering Institute, Carnegie Mellon University, 2006.

http://www.sei.cmu.edu/publications/documents/06.reports/06tr011.html

\section{[SCAMPI Upgrade Team 2006b]}

SCAMPI Upgrade Team. Standard CMMI Appraisal Method for Process Improvement (SCAMPI) A, Version 1.2: Method Definition Document (CMU/SEI2006-HB-002, ADA455859). Software Engineering Institute, Carnegie Mellon University, 2006.

http://www.sei.cmu.edu/publications/documents/06.reports/06hb002.html

\section{[SEI 2007a]}

Software Engineering Institute, Carnegie Mellon University. CMMI Transition Status, 2007 CMMI Steering Group Meeting (2007).

\section{[SEI 2007b]}

Software Engineering Institute, Carnegie Mellon University. Maturity Profile-About, http://www.sei.cmu.edu/appraisal-program/profile/index.html (2007).

\section{[SEI 2009a]}

Software Engineering Institute, Carnegie Mellon University. CMMI-Based Process Improvement Overview, http://www.sei.cmu.edu/products/courses/spi.overview.html (2009). 
[SEl 2009b]

Software Engineering Institute, Carnegie Mellon University. Introduction to CMMI, V1.2, http://www.sei.cmu.edu/products/courses/p44b.html (2009).

[SEI 2009c]

Software Engineering Institute, Carnegie Mellon University. Intermediate Concepts of CMMI, V1.2, http://www.sei.cmu.edu/products/courses/a02b.html (2009).

\section{[SEI 2009d]}

Software Engineering Institute, Carnegie Mellon University. CMMI, V1.2 Instructor Training, http://www.sei.cmu.edu/products/courses/p37b.html (2009).

\section{[SEl 2009e]}

Software Engineering Institute, Carnegie Mellon University. SCAMPI B and C Team Leader Training, http://www.sei.cmu.edu/products/courses/p53.html (2009).

\section{[SEI 2009f]}

Software Engineering Institute, Carnegie Mellon University. SCAMPI Lead Appraiser Training, http://www.sei.cmu.edu/products/courses/scampi-training.html (2009).

\section{[SEl 2009g]}

Software Engineering Institute, Carnegie Mellon University. SEI Partner Resource Center, https://partner-resources.sei.cmu.edu/ (2009).

\section{[SEI 2009h]}

Software Engineering Institute, Carnegie Mellon University. SEI Partner Resource Center, https://partner-resources.sei.cmu.edu/ (2009).

\section{[SEI 2009i]}

Software Engineering Institute, Carnegie Mellon University. SEI Partner Resource Center, https://partner-resources.sei.cmu.edu/ (2009).

\section{[SEl 2009j]}

Software Engineering Institute, Carnegie Mellon University. Implementing GoalDriven Measurements, http://www.sei.cmu.edu/products/courses/implement.goaldriven.sw.meas.html (2009).

\section{[SEI 2009k]}

Software Engineering Institute, Carnegie Mellon University. Analyzing Project Management Indicators, http://www.sei.cmu.edu/products/courses/p07b.html (2009).

\section{[SEl 2009I]}

Software Engineering Institute, Carnegie Mellon University. Understanding CMMI High Maturity Practices, http://www.sei.cmu.edu/products/courses/high-maturitystatistics.html (2009). 


\section{[SEI 2009m]}

Software Engineering Institute, Carnegie Mellon University. Improving Process Performance Using Six Sigma, http://www.sei.cmu.edu/products/courses/p49b.html (2009).

\section{[SEI 2009n]}

Software Engineering Institute, Carnegie Mellon University. Designing Products and Processes Using Six Sigma, http://www.sei.cmu.edu/products/courses/p56b.html (2009).

\section{[SEI 2009o]}

Software Engineering Institute, Carnegie Mellon University. Mastering Process Improvement, http://www.sei.cmu.edu/products/courses/master-processimprove.html (2009).

\section{[SEI 2009p]}

Software Engineering Institute, Carnegie Mellon University. Consulting Skills

Workshop, http://www.sei.cmu.edu/products/courses/cons.skills.wkshop.html (2009).

\section{[SEI 2009q]}

Software Engineering Institute, Carnegie Mellon University. Managing Technological Change, http://www.sei.cmu.edu/products/courses/mtc.html (2009).

\section{[SEI 2009r]}

Software Engineering Institute, Carnegie Mellon University. CMMI Transition Status, CMMI Steering Group Meeting (2009).

\section{[Spaulding 2005]}

Spaulding, Dale R. CMMI-ISO: Can't We All Just Get Along?

http://www.dtic.mil/ndia/2005cmmi/tuesday/spaulding.pdf (2005).

\section{[Tuffley 2004]}

Tuffley, Angela; Rout, Terrence P.; Stone-Tolcher, Mark; \& Gray, Ian. ISO 9001:2000 and the Capability Maturity Model Integration (CMMI).

http://www.aoq.asn.au/conference2004/qualcon_2004_merchandise.html (2004).

\section{[Vianna 2006]}

Vianna, Sidney. "AS9110 Keep 'em Flying." Quality Digest 26, 8 August 2006, 68-71.

\section{[Vickroy 2004]}

Vickroy, R. Why Be Assessed to the Most Prevalent Standard in Use Today?

Crosstalk 17, 6 June 2004 4-7.

http://www.stsc.hill.af.mil/crosstalk/2004/06/index.html

\section{[Violino 2005]}

Violino, Bob. Frameworks Boost Business Efficiency. Optimize Magazine 4, 3 March 2005, 68-70. 
[Wynn 2005]

Wynn, Dave. Surveillance-A One-Stop Shop? Obtaining Maximum Advantage From Your Surveillance Audit. Tick IT International 4Q05, 1, 14-21.

[Wynn 2006]

Wynn, Dave. A One-Stop Shop?-Part II: Obtaining Maximum Advantage From Your Surveillance Audit. Tick IT International 1Q06, 1, 3-11.

[Wynn 2007]

Wynn, Dave. A One-Stop Shop? - Part III: Obtaining Maximum Advantage From Your Surveillance Audit. Tick IT International 2Q07, 1, 3-9. 


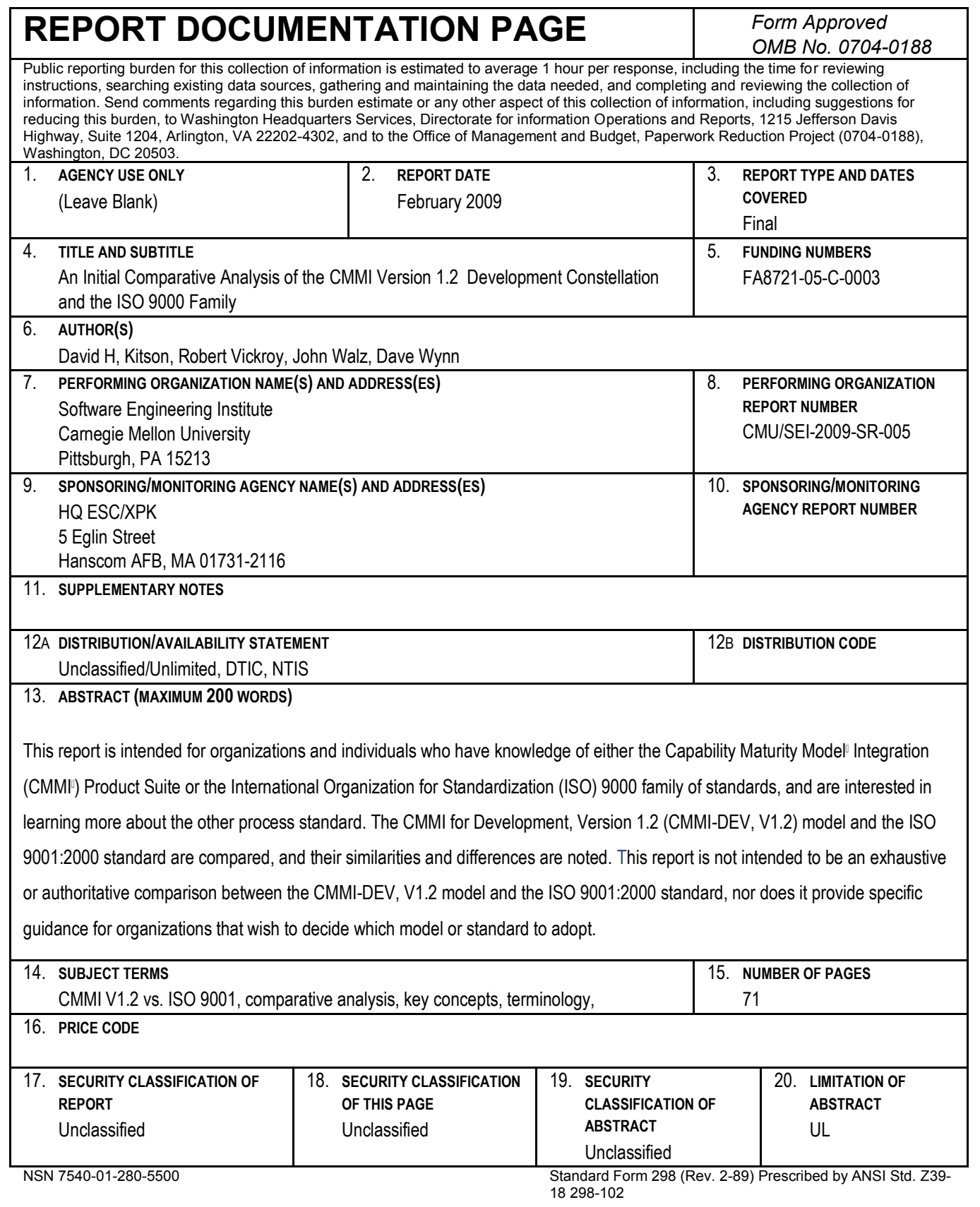

